\title{
Phenols and Polyphenols as Carbonic Anhydrase Inhibitors
}

\author{
Anastasia Karioti ${ }^{1, *}$, Fabrizio Carta ${ }^{2}$ and Claudiu T. Supuran ${ }^{2, *}$ \\ 1 Laboratory of Pharmacognosy, School of Pharmacy, Aristotle University of Thessaloniki, University Campus, \\ Thessaloniki 54124, Greece \\ 2 Neurofarba Department, Sezione di Chimica Farmaceutica e Nutraceutica, Università degli Studi di Firenze, \\ Via U. Schiff 6, I-50019 Sesto Fiorentino (Firenze), Italy; fabrizio.carta@unifi.it \\ * Correspondence: akarioti@pharm.auth.gr (A.K.); claudiu.supuran@unifi.it (C.T.S.); \\ Tel.: +30-231-099-0356 (A.K.); +39-055-457-3729 (C.T.S.); Fax: +39-055-457-3385 (C.T.S.)
}

Academic Editor: Jean-Yves Winum

Received: 6 November 2016; Accepted: 28 November 2016; Published: 2 December 2016

\begin{abstract}
Phenols are among the largest and most widely distributed groups of secondary metabolites within the plant kingdom. They are implicated in multiple and essential physiological functions. In humans they play an important role as microconstituents of the daily diet, their consumption being considered healthy. The physical and chemical properties of phenolic compounds make these molecules versatile ligands, capable of interacting with a wide range of targets, such as the Carbonic Anhydrases (CAs, EC 4.2.1.1). CAs reversibly catalyze the fundamental reaction of $\mathrm{CO}_{2}$ hydration to bicarbonate and protons in all living organisms, being actively involved in the regulation of a plethora of patho/physiological processes. This review will discuss the most recent advances in the search of naturally occurring phenols and their synthetic derivatives that inhibit the CAs and their mechanisms of action at molecular level. Plant extracts or mixtures are not considered in the present review.
\end{abstract}

Keywords: carbonic anhydrase inhibitors (CAIs); metalloenzymes; phenols; polyphenols; flavonoids

\section{Introduction}

\subsection{The Carbonic Anhydrases Family, Occurrence and Role}

$\mathrm{CO}_{2}$, bicarbonate and protons are an essential molecule and ions for many important physiologic processes occurring in all living organisms, including Archaea, Bacteria, and Eukarya [1,2]. However the uncatalyzed rate of interconversion of such species is too slow to meet the physiological needs of most biochemical processes [2,3]. This task is efficiently accomplished by the carbonic anhydrases (CAs, EC 4.2.1.1). This superfamily of metalloenzymes possess within their active sites a highly nucleophilic metal hydroxide species, such as zinc(II), cadmium(II) or iron (II) hydroxide, depending on the class [2,3]. To date seven not-genetically related CA families are reported, indicated with the Greek letters $\alpha-, \beta-, \gamma-, \delta-, \zeta-\eta$ - and $\theta-[1-9]$. All the CA families have been thoroughly characterized by means of kinetic and structural features, with the exception of the $\delta-, \eta$ - and $\theta-C A s$, for which only kinetic data are available so far [8-11]. The $\alpha$-CAs are mainly distributed among the vertebrates, protozoa, algae, cytoplasm of green plants and in many Bacteria species. Since $\alpha$-CAs are the only superfamily expressed in humans, they are also the most investigated ones for medicinal chemistry purposes [1-5,8,12-17]. Mammals (except the primates) possess $16 \alpha$-CA-isoforms, and among them three are devoid of catalytic activity [1,2]. The distribution of the various isoforms differs within tissues, cellular compartments as well as in modification of physio/pathological conditions $[1,2]$. The inhibition and activation mechanisms of CAs are well understood processes at a molecular 
level. The classical CA inhibitors (CAIs) such as the primary sulfonamides and their bioisosters (the sulfamides and sulfamates) as well as the thiocyanates, tightly bind to the $\mathrm{Zn}$ (II) ion within the enzymatic active site, thus interrupting the carbon dioxide hydration cycle $[1,2,12]$. Although the sulfonamides are in clinical use as CAIs for almost 70 years they usually are associated to various side effects, which among others include hypersensitivity $[1,12,13]$. In the search for new and more effective drug candidates, natural products are indeed of particular interest. Up to now coumarins [18], polyamines, [19] and phenols $[20,21]$ were revealed as interesting alternatives. The coumarins acts as prodrugs, [18] the simple phenols and polyamines anchor to the $\mathrm{Zn}$ (II)-bound water or hydroxide ion [19-21]. These different modes of action remarked many structural differences occurring between the CA isoforms and never explored before, thus paving the way for the design of new CAIs with high isoform selectivity and of particular interest for the future development as drug leads.

All the above considerations are of particular interest, as selective CA targeting is the crucial aspect for the successful pharmacological treatment of diseases in which such enzymes are involved. Besides the use of CAI-based drugs for the treatment of glaucoma, oedema and altitude sickness, CAs are established targets for the prognosis and treatment and of hypoxic tumors [22].

To date the hCA IX monoclonal chimeric antibody girentuximab (Rencarex ${ }^{\circledR}$ ), and its iodo radiolabeled derivative (Redectane ${ }^{\circledR}$ ) are marketed for both the treatment of renal cell carcinoma (RCC) and for imaging purposes respectively. Recent advances account for the introduction in phase I clinical trials of the primary sulfonamide small molecule SLC-0111 for the treatment of metastatic solid tumors in patients showing positive response to hCA IX and XII markers [23]. hCAs are also valid therapeutic targets for the treatment of osteoporosis [24], central-nervous-system (CNS) affecting diseases such as Alzheimer or epilepsy [17,25-27], as well as for the treatment of obesity [28,29]. A research stream of particular interest is also represented by development of new antiinfectives by means of the selective targeting of the CAs expressed in bacteria, fungi and protozoa which represent the etiologic agents of various infectious diseases [30,31]. The development of new and more efficient antiinfectives is a field of prior interest in medicinal chemistry since many resistant bacterial strains are seriously jeopardizing the currently used pharmacological drugs. In this context natural products constitute a remarkable source of highly promising lead compounds for future development as next generation drugs.

\subsection{Plant Phenolics}

Phenols and polyphenols constitute one of the largest and most ubiquitous classes of secondary metabolites in the plant kingdom. They are widely distributed in the Pteridophyta and Spermatophyta taxa (Gymnospermae and Angiospermae), whereas they are less common in bacteria, fungi and algae [32].

Simple phenols comprise structures with one aromatic ring, substituted with one or more hydroxyl moieties (Figure 1). Most phenols of natural origin have at least two hydroxyls in their structure and are generated biosynthetically from the shikimate (phenylpropanoid) pathway $\left(\mathrm{C}_{6}-\mathrm{C}_{3}\right)$ through a series of reactions including decarboxylation, dehydration, and oxidative cleavage [33-35].

Polyphenols have at least two phenolic rings in their structure and are characterized by a wide structural diversity (Figures 2 and 3). They derive from the shikimate (phenylpropanoid) pathway, the polyketide (acetate) pathway or from a combination of both biosynthetic routes. Historically the term polyphenol referred to tannins (condensed, hydrolysable and elagitannins, Figure 2), which are complex polyphenolic compounds of polymeric nature with molecular masses ranging from 500 to $4000 \mathrm{Da}$, capable of interacting and binding with proteins. This property of tannins to act as protein precipitants has been exploited since antiquity in the processing of animal skin to leather $[33,36,37]$. 


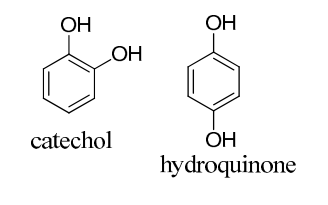

Simple phenols, Benzoquinones

$\mathrm{C}_{6}$

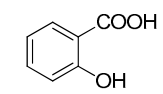

salicylic acid

Phenolic acids

$\mathrm{C}_{6}-\mathrm{C}_{1}$

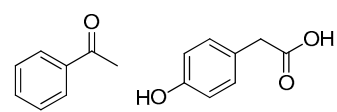

Acetophenones Phenylacetic acids

$\mathrm{C}_{6}-\mathrm{C}_{2}$<smiles>O=C(O)/C=C/c1ccc(O)c(O)c1</smiles>

caffeic acid

Hydroxycinnamic acids

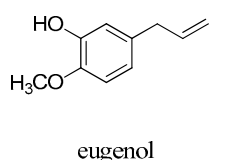

phenylpropenes<smiles>COc1cc2ccc(=O)oc2cc1O</smiles>

scopoletin

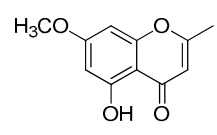

eugenin

$$
\mathrm{C}_{6}-\mathrm{C}_{3}
$$

coumarins

chromones<smiles>N#CC1CCCCC1C#N</smiles>

Figure 1. Main examples of phenols according to the classification of Harborne [32].

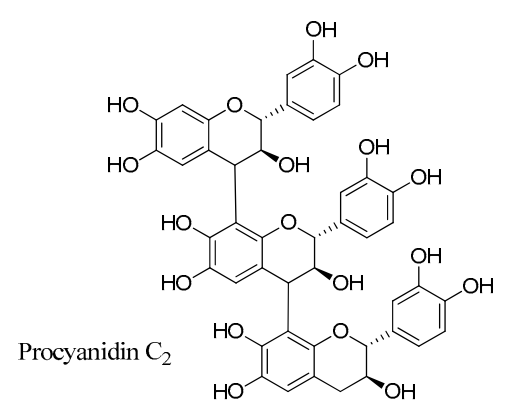<smiles>O=C(OC1CC2COC(OC(=O)c3cc(O)c(O)c(O)c3)C(OC(=O)c3cc(O)c(O)c(O)c3)C(OC(=O)c3cc(O)c(O)c(O)c3)C1C2OC(=O)c1cc(O)c(O)c(O)c1)c1cc(O)c(O)c(O)c1</smiles>

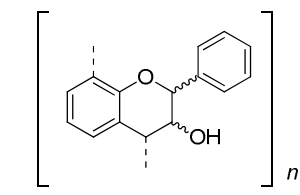

Procyanidins (Condensed tannins)

$\left(\mathbf{C}_{6}-\mathbf{C}_{3}\right)_{n}$

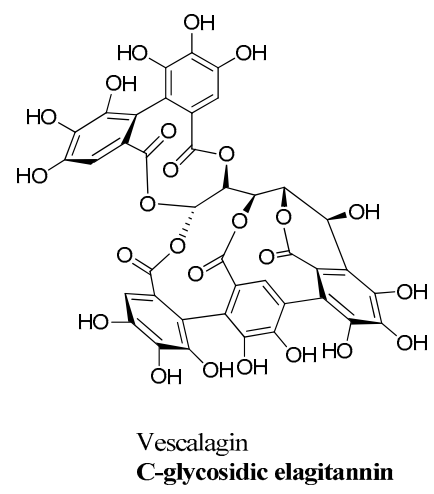

Figure 2. Examples of condensed (procyanidins), hydrolysable tannins and elagitannins.

With the advent of chromatographic techniques and the development of phytochemistry, the term polyphenol was expanded to include a wider range of molecules with at least two phenolic rings in their skeleton: xanthones, stilbenes and stilbenoids, depsides, phenylpropanoid derivatives, lignans and lignin (Figure 3) and, most importantly, flavonoids (Figure 4), which are by far the biggest group [32] of polyphenolic compounds.

More than 8000 flavonoids and derivatives thereof have been reported to date [38]. The term flavonoid refers to yellow (flavus = yellow) pigments which in their classical form incorporate a benzo[ $\gamma]$ pyrone system. However, under the same group several biogenetically relative secondary 
metabolites are comprised including the yellow pigments aurones and chalcones, the colorless flavanones and the red/blue anthocyanidins (Figure 4).

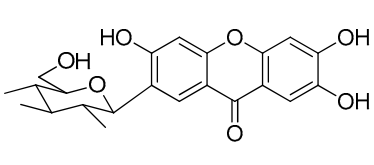

Mangiferin

Xanthones $\mathrm{C}_{6}-\mathrm{C}_{1}-\mathrm{C}_{6}$

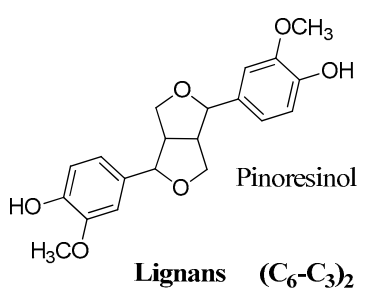<smiles>Oc1ccc(/C=C/c2cc(O)cc(O)c2)cc1</smiles>

trans-resveratrol

Stilbenes $\mathrm{C}_{6}-\mathrm{C}_{2}-\mathrm{C}_{6}$
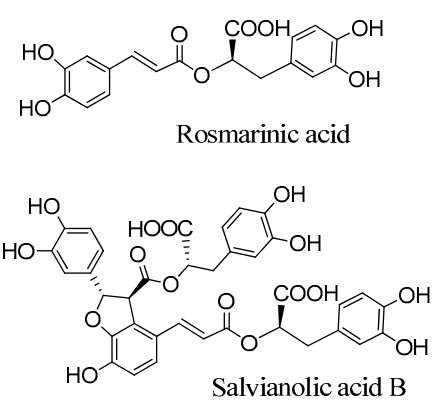

Depsides

Figure 3. Some examples of polyphenolic classes.
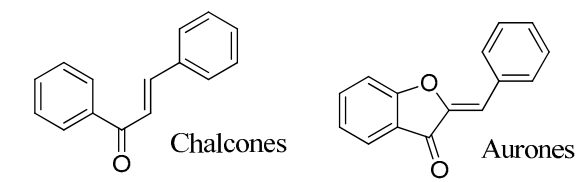<smiles>O=c1cc(-c2ccccc2)oc2ccccc12</smiles><smiles>O=C1CC(c2ccccc2)Oc2ccccc21</smiles><smiles>O=c1c(O)c(-c2ccccc2)oc2ccccc12</smiles><smiles>O=C1c2ccccc2OC(c2ccccc2)C1O</smiles><smiles>Oc1cc2ccccc2[o+]c1-c1ccccc1</smiles><smiles>O=c1c(-c2ccccc2)coc2ccccc12</smiles>

Isoflavones<smiles>OC1Cc2ccccc2OC1c1ccccc1</smiles>

Flavonoids

$\mathrm{C}_{6}-\mathrm{C}_{3}-\mathrm{C}_{6}$

Figure 4. Basic flavonoid structures.

In plants phenolics play a key role in many vital physiological processes, such as lignification, pigmentation of flowers and fruits, pollination, as growth factors, and they also govern plant responses towards environmental stress, such as protection from excess UV radiation, nutrient deficiency, drought stress, and most importantly they act as chemical defense against herbivores, insects and microbial pathogens [36,37]. For humans, plant phenolics are important constituents of many edible and medicinal plants and widely used in the food industry as flavorings, antioxidants and antibacterial agents $[39,40]$. Phenols and polyphenols have attracted great interest due to their wide presence in our daily diet and most importantly due to their antioxidant properties. Many efforts have been done to estimate the daily intake in plant phenolics. Humans seem to have adapted their enzymatic systems and only a small portion of the phenolic content in foods reaches the tissues unaltered [41]. Although the relationships between food phenolics and health are not fully understood, epidemiological studies in humans demonstrate that consumption of food rich in polyphenolic constituents might be beneficial especially for some age-related disorders, such as cardiovascular and neurodegenerative diseases, type II diabetes and cancers [41-43].

The ability of plant phenolics to interact with a plethora of targets and cause such a broad range of activities should be attributed to the physicochemical properties of the main structural unit, the 
phenolic ring [41]. The phenolic moiety has an amphiphilic character. The presence of the hydrophobic planar aromatic ring is responsible for hydrophobic interactions ( $\pi$-stacking), whereas at the same time the polar hydroxyl groups can participate in hydrogen bonding. This dual behavior allows these molecules to bind to the amino acid residues of several proteins, enzymes or receptors. Furthermore the occurrence of ortho-hydroxyl groups renders them excellent antioxidant agents and chelating factors. These properties render plant phenolics as excellent candidate molecules to study the inhibition of metalloenzymes.

One such an enzyme is the family of the carbonic anhydrases (CAs, EC 4.2.1.1) which is the subject of the present review. Simple phenols and polyphenols of natural origin are discussed, along with their synthetic derivatives. The inhibition mechanisms and possible structure activity relationships are also presented. Since coumarins are discussed in another article of this special issue they are not included in the present one. Only reports on pure compounds were taken into consideration. This is an update of previous reviews [44,45].

\section{Phenols and Polyphenols as Effective Carbonic Anhydrase Inhibitors}

\subsection{Inhibition Mechanism of Phenol}

Phenol, the simplest member of this family of compounds was reported to be a competitive inhibitor of human (h) Carbonic Anhydrase II (hCA II) [46,47]. The X-ray crystal structure of its adduct with hCA II was studied and revealed the binding of two phenol molecules to the enzyme. The first one was located in a hydrophobic patch about $15 \AA$ away from the catalytic zinc ion thus it is likely that this binding does not interfere with the enzymatic catalytic activity. However, the second phenol molecule was found within the active site and showed a new binding mode. Indeed, this molecule did not coordinate to the zinc ion, but was anchored to the active site through two hydrogen bonds of the $\mathrm{OH}$ moiety with the zinc-bound water/hydroxide ion and the NH amide of Thr 199. Furthermore, the aromatic ring was found to lie in a hydrophobic pocket of the active site, delimited by residues Val 121, Val 143, Leu 198, and $197 \operatorname{Trp} 209$, thus contributing to the complex stabilization [48] (Figure 5).

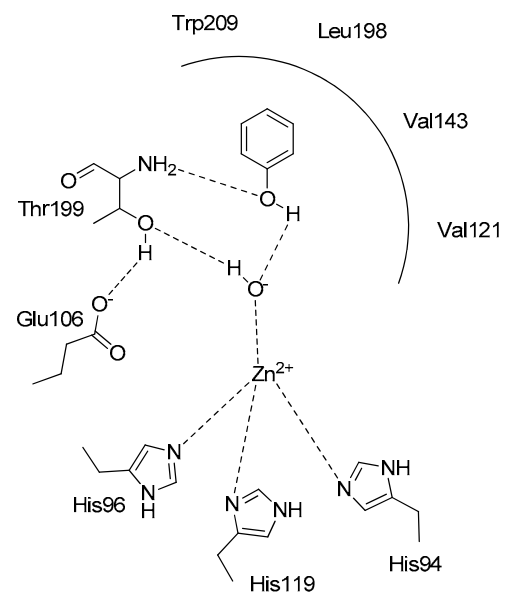

Figure 5. Schematic representation of the binding mode of phenol within the hCA II active site [48].

\subsection{Simple Phenols}

These findings opened the way for the exploration of other phenolic and polyphenolic natural products. In vitro kinetic studies of a series of phenols widely available on the market such as salicylic acid, resorcinol, $p$-coumaric, caffeic, ferulic, gallic acids, etc., showed that these are affective CA inhibitors in the low micromolar range (Figure 6) [45,46]. 
<smiles>Oc1ccccc1</smiles><smiles>Oc1ccccc1O</smiles>

phenol

catechol

2<smiles>O=C(O)/C=C/c1ccc(O)cc1</smiles>

p-coumaric acid

6<smiles>O=C(O)c1ccc(O)cc1</smiles>

p-hydroxybenzoic acid

3<smiles>O=C(O)/C=C/c1ccc(O)c(O)c1</smiles>

caffeic acid<smiles>O=C(O)c1cc(O)c(O)c(O)c1</smiles>

gallic acid

4<smiles>COc1cc(C(=O)O)cc(OC)c1O</smiles>

syringic acid

5<smiles>COc1cc(/C=C/C(=O)O)ccc1O</smiles>

ferulic acid

8

Figure 6. Some phenolic compounds as CAIs [45].

The presence of free hydroxyl groups at position $4^{\prime}$ in combination with the double bond in the phenylpropanoid skeleton, as in $p$-coumaric acid, clearly enhanced the inhibitory activity when compared to the simple phenol moiety. Similar results were obtained in a further study with a small group of monophenolic constituents, where trans-cinnamic (14), o-coumaric (15) and chlorogenic (16) acids were more effective than simple phenolic constituents such as benzoic acid (9) [45] (Figure 7 and Table 1).<smiles>O=C(O)c1ccccc1</smiles>

9<smiles>O=C(O)c1cccc(O)c1</smiles>

10<smiles>CCCOC(=O)c1ccc(O)cc1</smiles>

11<smiles>O=C(O)c1ccc(O)c(O)c1</smiles>

12<smiles>COc1cc(C(=O)O)ccc1O</smiles><smiles>O=C(O)/C=C/c1ccccc1</smiles>

14<smiles>O=C(O)/C=C/c1ccccc1O</smiles>

15<smiles>O=C(/C=C/c1ccc(O)c(O)c1)O[C@H]1C[C@](O)(C(=O)O)CC(O)[C@H]1O</smiles>

16<smiles>COc1ccccc1O</smiles>

17<smiles>COc1cc(C)ccc1O</smiles><smiles>COc1cc(C=O)ccc1O</smiles>

22<smiles>COc1cc(C=O)cc(OC)c1O</smiles>

23<smiles>CCCc1ccc(O)c(OC)c1</smiles><smiles>C=CCc1ccc(O)c(OC)c1</smiles><smiles>C/C=C/c1ccc(O)c(OC)c1</smiles>

21<smiles>Oc1ccccc1O</smiles>

24<smiles>Cc1cccc(O)c1O</smiles>

25<smiles>Cc1ccc(O)c(O)c1</smiles>

26<smiles>COc1cccc(O)c1O</smiles>

27

Figure 7. Structures of tested phenols: benzoic acid (9), $m$-benzoic acid (10), propylparaben (11), protocatechuic acid (12), vanillic acid (13), cinnamic acid (14), o-coumaric acid (15), chlorogenic acid (16), guaiacol (17), 4-methylguaiacol (18), 4-propylguaiacol (19), eugenol (20), isoeugenol (21), vanillin (22), syringaldehyde (23), catechol (24), 3-methylcatechol (25), 4-methylcatechol (26), 3-methoxycatechol (27) [45]. 
Table 1. Inhibition data of compounds 9-16 [45].

\begin{tabular}{ccc}
\hline \multirow{2}{*}{ Compound } & \multicolumn{2}{c}{ IC $_{\mathbf{5 0}}(\mu \mathrm{g} / \mathbf{m L})^{\mathbf{a}}$} \\
\cline { 2 - 3 } & hCA I & hCA II \\
\hline Benzoic acid (9) & 1.31 & 1.12 \\
m-hydroxybenzoic acid (10) & 1.33 & 1.00 \\
Propylparaben (11) & 0.84 & 0.82 \\
Protocatechuic acid (12) & 1.31 & 1.15 \\
Vanillic acid (13) & 0.52 & 0.36 \\
o-coumaric acid (14) & 0.93 & 0.22 \\
trans-cinnamic (15) & 0.11 & 0.09 \\
Chlorogenic acid (16) & 0.98 & 0.88 \\
\hline
\end{tabular}

${ }^{a}$ From three different assays, errors $\pm 5 \%-10 \%$ of the reported value.

In another study several derivatives of guaiacol and catechol (17-27) were considered for their CA inhibitory activity against human CA I, II, IX and XII isoforms [49]. Among the compounds tested in vitro were the volatile constituents eugenol (20), isoeugenol (21) and vanillin (22), which are major components of many aromatic herbs and spices such as clove, basil, anise seed, Vanilla sp., etc. All compounds showed micromolar inhibition potencies spanning between 2.2-10.92 $\mu \mathrm{M}$ with the exception of the catechol (Table 2). Among the tested phenolic derivatives, compounds 4-methyl-catechol (26) and 3-methoxycatechol (27) showed potent activity as inhibitors of the tumour-associated transmembrane isoforms hCA IX and XII with $\mathrm{K}_{\mathrm{I}}$ values in the submicromolar range.

Table 2. Inhibition constants of certain phenolic compounds derived from guaiacol and catechol against four human carbonic anhydrase isoenzymes (hCA I, II, IX and XII) using an esterase bioassay [49].

\begin{tabular}{ccccc}
\hline \multirow{2}{*}{ Compound } & \multicolumn{4}{c}{$\mathbf{K}_{\mathbf{I}}(\boldsymbol{\mu M})^{\mathbf{a}}$} \\
\cline { 2 - 5 } & hCA I & hCA II & hCA IX & hCA XII \\
\hline Guaiacol (17) & 7.50 & 5.63 & 9.98 & 9.83 \\
4-Methylguaiacol (18) & 9.15 & 7.74 & 9.89 & 8.55 \\
4-Propylguaiacol (19) & 10.34 & 8.51 & 9.01 & 9.12 \\
Eugenol (20) & 8.32 & 7.27 & 9.62 & 8.89 \\
Isoeugenol (21) & 10.29 & 6.73 & 9.32 & 9.13 \\
Vanillin (22) & 11.37 & 7.15 & 9.81 & 8.39 \\
Syringaldehyde (23) & 10.92 & 6.68 & 9.11 & 7.70 \\
Catechol (24) & 247.50 & 5.51 & 373.23 & 515.98 \\
3-Methylcatechol (25) & 5.95 & 4.69 & 9.55 & 7.22 \\
4-Methylcatechol (26) & 6.16 & 2.76 & 8.11 & 6.58 \\
3-Methoxycatechol (27) & 6.32 & 2.20 & 7.83 & 7.53 \\
\hline
\end{tabular}

${ }^{\text {a }}$ From three different assays, errors $\pm 5 \%-10 \%$ of the reported value.

Combination of the phenolic moiety with other functional groups is a common strategy to obtain products with enhanced activity. For example, in the so-called "sugar approach" the incorporation of a hydrophilic moiety of a sugar permits to the molecule to anchor in a different manner to the enzyme cavity. Furthermore, it increases its selectivity towards the membrane bound CA isoforms over the cytosolic ones $[50,51]$. This is desirable since selectivity against specific hCA isoforms might reduce side effects.

In this concept, a series of synthetic $C$-cinnamoyl glycosides were synthetized and considered for the inhibition on twelve mammalian isoforms of carbonic anhydrase (Figure 8) [52]. These compounds combined two functional groups with known activity against the hCAs: the cinnamoyl and the glucose group. In order to avoid undesirable degradation, the $\mathrm{O}$-glycosidic bond was replaced by the more stable C-glycosidic one. The C-cinnamoyl glycosides (28-35) were generally effective CAs, with 
inhibition constants in the low micromolar range against CA I, II, IV, VA, VB, VI, VII, IX, XII, XIII, XIV and ineffective inhibitors of CA III (Table 3).

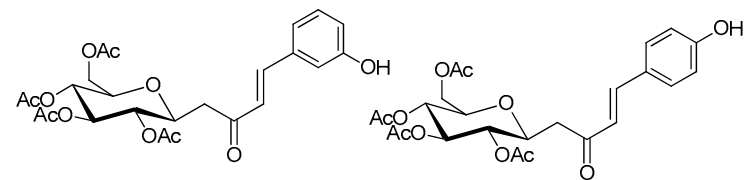

28<smiles>O=C(/C=C/c1cccc(O)c1)COC1C(O)C(O)C(O)COC1C(O)CC(=O)/C=C/c1ccc(O)cc1</smiles>

32

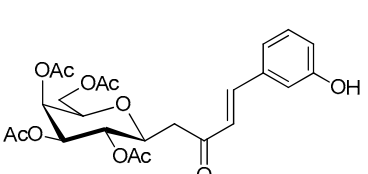

30<smiles>O=C(/C=C/c1cccc(O)c1)CC(O)C1OCC(O)(O)C(O)C1O</smiles>

34

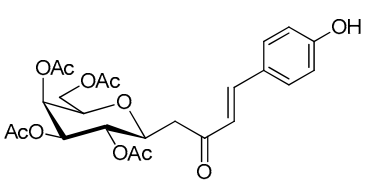

31<smiles>O=C(/C=C/c1ccc(O)cc1)CC(O)OC(O)C(O)O</smiles>

Figure 8. Structures of the cinnamoyl glycosides 28-35 [52].

Table 3. Inhibition of mammalian $\alpha$-CA with the C-cinnamoyl glycosides 28-35 and phenol 1.

\begin{tabular}{|c|c|c|c|c|c|c|c|c|c|c|c|c|}
\hline \multirow[b]{2}{*}{ No. } & \multicolumn{12}{|c|}{$K_{I}(\mu M)^{a}$} \\
\hline & $\begin{array}{c}\text { hCA } \\
\text { I }\end{array}$ & $\begin{array}{c}\text { hCA } \\
\text { II }\end{array}$ & $\begin{array}{c}\text { hCA } \\
\text { III }\end{array}$ & $\begin{array}{c}\text { hCA } \\
\text { IV }\end{array}$ & $\begin{array}{c}\text { hCA } \\
\text { VA }\end{array}$ & $\begin{array}{c}\text { hCA } \\
\text { VB }\end{array}$ & $\begin{array}{c}\text { hCA } \\
\text { VI }\end{array}$ & $\begin{array}{c}\text { hCA } \\
\text { VII }\end{array}$ & $\begin{array}{c}\text { hCA } \\
\text { IX }\end{array}$ & $\begin{array}{c}\text { hCA } \\
\text { XII }\end{array}$ & $\begin{array}{l}\text { hCA } \\
\text { XIII }\end{array}$ & $\begin{array}{l}\text { hCA } \\
\text { XIV }\end{array}$ \\
\hline 28 & 8.5 & 7.0 & $>100$ & 5.6 & 9.8 & 6.0 & 8.8 & 9.5 & 5.2 & 6.7 & 5.1 & 5.9 \\
\hline 29 & 5.7 & 3.9 & $>100$ & 4.9 & 8.4 & 4.0 & 6.2 & 6.3 & 5.9 & 6.2 & 4.9 & 5.6 \\
\hline 30 & 5.1 & 7.1 & $>100$ & 7.8 & 9.5 & 6.9 & 7.7 & 7.1 & 3.3 & 3.9 & 7.2 & 4.6 \\
\hline 31 & 9.3 & 5.5 & $>100$ & 6.7 & 9.3 & 5.2 & 7.9 & 5.8 & 2.9 & 4.2 & 6.7 & 2.3 \\
\hline 32 & 6.8 & 7.8 & $>100$ & 8.3 & 7.4 & $>100$ & $>100$ & 4.9 & 4.5 & 7.4 & 8.8 & 4.3 \\
\hline 33 & 3.7 & 8.8 & $>100$ & 7.1 & 4.4 & $>100$ & $>100$ & 8.5 & 8.2 & 8.7 & 8.6 & 7.1 \\
\hline 34 & 3.6 & 3.1 & $>100$ & 9.2 & 3.4 & $>100$ & 8.1 & 9.0 & 9.2 & 8.4 & 8.6 & $>100$ \\
\hline 35 & 5.5 & 6.8 & 8.4 & 8.4 & 8.0 & $>100$ & $>100$ & 9.3 & 8.2 & 6.8 & $>100$ & $>100$ \\
\hline 1 & 10.2 & 5.5 & 2.7 & 9.5 & 218 & 543 & 208 & 710 & 8.8 & 9.2 & 697 & 11.5 \\
\hline
\end{tabular}

Another hybrid molecule recently investigated against several hCA isozymes [53] is Dodoneine 36, one of the active principles of the medicinal plant Agelanthus dodoneifolius (DC) Polhilland Wiens. The plant is used in traditional medicine for the treatment of hypertension. Structurally 36 incorporates both the phenol and lactone ( $\alpha$-pyrone) moieties. Dodoneine showed to be selective in inhibiting the hCA isoforms I, III, IV, XIII and XIV with $\mathrm{K}_{\mathrm{I}} \mathrm{s}$ in the range of 5.5-10.4 $\mu \mathrm{M}$. CA I, III and XIII are cytosolic, CA IV is localized in plasma membrane and hCA XIV is a membrane bounded isozyme. Further in vitro and in vivo studies in rat aorta and vascular smooth muscle cells showed that hCA II, III, XIII and XIV were expressed in rat aorta while only the hCA isoforms III, XIII and XIV were expressed in smooth muscle cells. Thus it is reasonable to assume that dodoneine induced vasorelaxation by a dual mode of action including both block of the L-type calcium channels and inhibition of the hCA isoforms therein expressed [54]. A series of synthetic analogues of dodoneine (37-41), reported in Figure 9, were prepared and tested for their inhibition properties against the hCAs. Among them the bicyclic compound 40 which is normally found in the plant in small amounts and its hydroxylated derivative 41 and the fluorinated analogue 39 (Table 4). Compound 39 inhibited all hCA isoforms, while 41 inhibited selectively hCA III $\left(\mathrm{K}_{\mathrm{I}}=5.1 \mathrm{nM}\right)$ and $\mathrm{mCA}$ XIII $\left(\mathrm{K}_{\mathrm{I}}=340 \mathrm{nM}\right)$. 
<smiles>O=C1C=CCC(CC(O)CCc2ccc(O)cc2)O1</smiles>

36<smiles>O=C1C=CC[C@H](CC(F)CCc2ccc(O)cc2)O1</smiles>

39<smiles>O=C1C=CC[C@H](C[C@@H](O)CCc2ccc(O)cc2O)O1</smiles>

37<smiles></smiles>

40<smiles>O=C1C=CC[C@@H](C[C@@H](O)CCc2cc(Br)c(O)cc2Br)O1</smiles>

38<smiles>O=C1C[C@H]2C[C@@H](CCc3ccc(O)cc3O)C(=O)C[C@H]2O1</smiles>

41

Figure 9. Structures and hCA inhibition data of dodoneine (36) and its analogues $\mathbf{3 7 - 4 1}$ by a stopped flow $\mathrm{CO}_{2}$ hydrase assay [53].

Table 4. Structures and hCA inhibition data of dodoneine (36) and its analogues 37-41 by a stopped flow $\mathrm{CO}_{2}$ hydrase assay [53].

\begin{tabular}{|c|c|c|c|c|c|c|c|c|c|c|c|c|}
\hline \multirow[b]{2}{*}{ No. } & \multicolumn{12}{|c|}{$K_{I}(\mu M)^{a}$} \\
\hline & $\begin{array}{c}\text { hCA } \\
\text { I }\end{array}$ & $\begin{array}{c}\text { hCA } \\
\text { II }\end{array}$ & $\begin{array}{c}\text { hCA } \\
\text { III }\end{array}$ & $\begin{array}{l}\text { hCA } \\
\text { IV }\end{array}$ & $\begin{array}{c}\text { hCA } \\
\text { VA }\end{array}$ & $\begin{array}{c}\text { hCA } \\
\text { VB }\end{array}$ & $\begin{array}{c}\text { hCA } \\
\text { VI }\end{array}$ & $\begin{array}{l}\text { hCA } \\
\text { VII }\end{array}$ & $\begin{array}{c}\text { hCA } \\
\text { IX }\end{array}$ & $\begin{array}{c}\text { hCA } \\
\text { XII }\end{array}$ & $\begin{array}{l}\text { hCA } \\
\text { XIII }\end{array}$ & $\begin{array}{l}\text { hCA } \\
\text { XIV }^{b}\end{array}$ \\
\hline 36 & 5.48 & ${ }_{-}^{\mathrm{c}}$ & 10.35 & 9.61 & c & c & ${ }_{-}^{c}$ & $\mathrm{c}$ & c & c & 9.27 & 9.34 \\
\hline 37 & 0.38 & $\mathrm{c}$ & c & 4.12 & $\overline{21} .6$ & $\overline{13} .7$ & c & $\mathrm{c}$ & 32.6 & $\overline{24} .5$ & 8.13 & 7.24 \\
\hline 38 & 0.76 & $\overline{21} .8$ & & 13.7 & 8.55 & 6.32 & & & 15.7 & 10.8 & 7.89 & 12.5 \\
\hline 39 & 0.13 & 36.9 & & 5.36 & 7.13 & 1.36 & ${ }_{-}^{c}$ & 24.9 & 3.57 & 1.48 & 0.96 & 2.44 \\
\hline 40 & c & c & 10.80 & c & c & ${ }_{-}^{c}$ & ${ }_{-}^{c}$ & ${ }_{-}^{c}$ & c & c & 0.91 & ${ }_{-}^{c}$ \\
\hline 41 & ${ }_{-}^{-} \mathrm{c}$ & ${ }_{-}^{-} \mathrm{c}$ & 5.13 & ${ }_{-}^{-} \mathrm{c}$ & ${ }_{-}^{-} \mathrm{c}$ & ${ }_{-}^{-} \mathrm{c}$ & ${ }_{-}^{-} \mathrm{c}$ & ${ }_{-}^{-}$ & ${ }_{-}^{c}$ & $-c$ & 0.34 & ${ }_{-}^{-} \mathrm{c}$ \\
\hline
\end{tabular}

\subsection{Polyphenols}

Recently rosmarinic acid (42) was reported to be a potent inhibitor of the hCA I and II isoenzymes at low micromolar range with $\mathrm{K}_{\mathrm{I}}$ values of $86.0 \mu \mathrm{M}$ and $57.0 \mu \mathrm{M}$, respectively (Figure 10) [55]. Rosmarinic acid is a powerful antioxidant found in many aromatic, medicinal and culinary herbs of the Lamiaceae family, such as rosemary, sage, oregano and thyme [56]. Chemically it belongs to the class of depsides, or the so-called labiataetannins [41], which are obtained by condensation of caffeic acid units or by combination of caffeic acid with 3,4-dihydroxyphenyl lactic acid, to form dimers, trimers and tetramers.<smiles>O=C(/C=C/c1ccc(O)c(O)c1)O[C@H](Cc1ccc(O)c(O)c1)C(=O)O</smiles>

42

Figure 10. Structure of rosmarinic acid (42).

Based on these results further investigations were carried out with the salvianolic acids 43-45 (Figure 11) isolated from Salvia miltiorrhiza (Lamiaceae) [57,58]. Salvia miltiorrhiza or Danshen is one of the most important herbal medicinal drugs in the Chinese Traditional Medicines (TCM) to treat bleeding disorders (e.g., menstrual bleeding) and blood stasis [59]. Salvianolic acids are together with tanshinones (lipophilic, diterpenic quinones) the main active principles of the herbal drug. 
These hydrophilic derivatives, abundant in the roots of the plant, incorporate three to four units of caffeic/3,4-dihydroxyphenyl lactic acids. They have attracted interest due to their protective roles in CNS neuronal injuries and degeneration. The main mechanism involved in such processes is the decrease of reactive oxygen species (ROS) levels. Furthermore, there is evidence of the protective role of salvianolic acids in several cardiovascular diseases, osteoporosis, liver fibrosis and hepatic failure [59-61].<smiles>O=C(OC(Cc1ccc(O)c(O)c1)C(=O)O)C(=CC=Cc1ccc(O)c(O)c1)c1ccc(O)c(O)c1O</smiles><smiles>O=C(O)OC(Cc1ccc(O)c(O)c1)C(=O)OC(=O)C1c2ccc(O)c(OCc3ccc(O)c(O)c3)c2C(C(=O)O)C1C(=O)O</smiles><smiles>O=C(/C=C/c1ccc(O)c2c1[C@H](C(=O)O[C@H](CO)Cc1ccc(O)c(O)c1)[C@H](c1ccc(O)c(O)c1)O2)O[C@@H](Cc1ccc(O)c(O)c1)C(=O)O</smiles>

Figure 11. Structures of salvianolic acids 43-45 from Salvia miltiorrhiza.

The CAs inhibition studies reported in Table 5 clearly showed that depsides $\mathbf{4 3 - 4 5}$ were ineffective hCA I and weak hCA II inhibitors. On the other hand, they were inhibitors of the hCA IV with $\mathrm{K}_{\mathrm{I}}$ values in the range of $62.2-102.1 \mathrm{nM}$ and comparable to the standard drug acetazolamide AAZ $(74.0 \mathrm{nM})$. Even if a proper structure-activity-relationship (SAR) consideration is difficult to be drawn it is noteworthy that the flexible and more containing catechol moieties salvianolic acids A and B (43 and 45) were better inhibitors when compared to the lithospermic acid 44. Furthermore, salvianolic acids $\mathrm{A}$ and $\mathrm{B}$ were medium and high nanomolar inhibitors $\left(\mathrm{K}_{\mathrm{I}} 39.8\right.$ and $453.6 \mathrm{nM}$ of the tumor associated CA XII. By contrast, lithospermic acid (44) showed to be a very potent hCA XII inhibitor with a $\mathrm{K}_{\mathrm{I}}$ value of $4.8 \mathrm{nM}$. The presence of ortho-hydroxyl moieties in these molecules, the possibility to release in situ caffeic acid or even the presence of free carboxyl groups are some of the structural characteristics that play an important role in the CA inhibitory activity. In any case such results put in evidence a new class of natural products which deserves further investigation in order to decipher a proper SAR correlation.

Table 5. Inhibition data of human CA isoforms hCA I, II, IV, VII and XII with salvianolic acids $\mathbf{4 3 - 4 5}$ reported here and the standard sulfonamide inhibitor acetazolamide (AAZ) by a stopped flow $\mathrm{CO}_{2}$ hydrase assay [58].

\begin{tabular}{cccccc}
\hline \multirow{2}{*}{ No. } & \multicolumn{5}{c}{$\mathbf{K}_{\mathbf{I}}(\mathbf{n M})^{\mathbf{a}}$} \\
\cline { 2 - 6 } & hCA I & hCA II & hCA IV & hCA VII & hCA XII \\
\hline Salvianolic Acid A (43) & $>10,000$ & 9594.4 & 66.6 & 71.4 & 39.8 \\
Lithospermic Acid (44) & $>10,000$ & $>10,000$ & 101.2 & 268.3 & 4.8 \\
Salvianolic Acid B (45) & $>10,000$ & $>10,000$ & 65.6 & 35.5 & 453.6 \\
AAZ & 250 & 12 & 74 & 2.5 & 5.7 \\
\hline
\end{tabular}

${ }^{a}$ From three different assays, errors $\pm 5 \%-10 \%$ of the reported value.

Another recent example is constituted by a series of phenolic acid esters (Scheme 1) incorporating caffeic, ferulic, and $p$-coumaric acid, and benzyl, $m / p$-hydroxyphenethyl- as well as $p$-hydroxy-phenethoxy-phenethyl moieties, which were investigated for their inhibitory effects against 
the mammalian isozymes of human $(\mathrm{h})$ or murine $(\mathrm{m})$ origin, hCA I-hCA XII, mCA XIII and hCA XIV [62]. These enzymes were inhibited in the submicromolar range by many of these derivatives (with $\mathrm{K}_{\mathrm{I}} \mathrm{S}$ of $0.31-1.03 \mu \mathrm{M}$ against hCA VA, VB, VI, VII, IX and XIV). The off-target, highly abundant isoforms hCA I and II, as well as hCA III, IV and XII were poorly inhibited by many of these esters, although the original phenolic acids were micromolar inhibitors. These phenols, like others investigated earlier, possess a CA inhibition mechanism distinct of the sulfonamides/sulfamates, clinically used drugs for the treatment of a multitude of pathologies, but with severe side effects due to hCA I/II inhibition.<smiles>[R]c1cc(/C=C/C(=O)O)ccc1O</smiles>

$$
\begin{array}{ll}
\text { caffeic acid: } & R^{1}=O H \\
\text { ferulic acid: } & R^{1}=O M e \\
\text { coumaric acid: } & R^{1}=H
\end{array}
$$<smiles>CC(C)CC(C)CC(C)C</smiles>

$\mathrm{A}: \mathrm{n}=2 ; \mathrm{R}^{2}=p-\mathrm{OH}$

B: $\mathrm{n}=2 ; \mathrm{R}^{2}=m-\mathrm{OH}$

C: $n=1 ; R^{2}=H$<smiles>[R]c1cccc(/C=C/C(=O)OC(C)C)c1</smiles>

46: $\mathrm{R}^{1}=\mathrm{OH} ; \mathrm{n}=2 ; \mathrm{R}^{2}=p-\mathrm{O}\left(\mathrm{CH}_{2}\right)_{2}-\mathrm{C}_{6} \mathrm{H}_{4}-p-\mathrm{OH}$

47: $\mathrm{R}^{1}=\mathrm{OH} ; \mathrm{n}=2 ; \mathrm{R}^{2}=m-\mathrm{O}\left(\mathrm{CH}_{2}\right)_{2}-\mathrm{C}_{6} \mathrm{H}_{4}-m-\mathrm{OH}$

48: $\mathrm{R}^{1}=\mathrm{OMe} ; \mathrm{n}=1 ; \mathrm{R}^{2}=\mathrm{H}$

49: $\mathrm{R}^{1}=\mathrm{OMe} ; \mathrm{n}=2 ; \mathrm{R}^{2}=p-\mathrm{OH}$

50: $\mathrm{R}^{1}=\mathrm{OMe} ; \mathrm{n}=2 ; \mathrm{R}^{2}=m-\mathrm{OH}$

51: $\mathrm{R}^{1}=\mathrm{H} ; \mathrm{n}=1 ; \mathrm{R}^{2}=\mathrm{H}$

52: $\mathrm{R}^{1}=\mathrm{H} ; \mathrm{n}=2 ; \mathrm{R}^{2}=p-\mathrm{OH}$

53: $\mathrm{R}^{1}=\mathrm{H} ; \mathrm{n}=2 ; \mathrm{R}^{2}=m-\mathrm{OH}$

Scheme 1. Synthesis of phenolic derivatives 46-53 Reagents and conditions: (i) THF, Ph3P, DIAD, $0{ }^{\circ} \mathrm{C}[62]$.

In an attempt to find new chemotypes, two floroglucinol derivatives $\mathbf{5 4 , 5 5}$ were prepared and tested against hCA I and hCA II (Scheme 2). Unfortunately, none of the compounds proved to be active [63].<smiles>COc1ccc(/C=C/C(=O)O)cc1</smiles><smiles>COc1ccc(/C=C/CBr)cc1</smiles><smiles>CC#CC</smiles><smiles>COc1ccc(/C=C/Cc2c(O)cc(O)cc2O)cc1</smiles>

54<smiles>COc1ccc(/C=C/Cc2c(O)cc(O)c(C/C=C/c3ccc(OC)cc3)c2O)cc1</smiles>

55

Scheme 2. Synthesis of floroglucinol derivatives 54 and 55. Reagents and conditions: $\mathrm{NaBH}_{4}, \mathrm{EtOH}$, $0{ }^{\circ} \mathrm{C}, 30 \mathrm{~min}, 98 \%$; (ii) $\mathrm{PBr}_{3}$, diethylether, $0{ }^{\circ} \mathrm{C}, 1 \mathrm{~h}, 85 \%$; (iii) $\mathrm{NaH}$, THF, r.t., $17 \mathrm{~h}, 26 \%$.

\subsection{Flavonoids}

Data of the interaction of flavonoids with CAs indicate that these may be another category of CAIs of interest, which can be used as leads for generating more potent CAIs. Preliminary test of a small number of basic flavonoid structures 56-59 (Figure 12) against hCA I, II, IX and XII showed that these act as low micromolar inhibitors and their effect is independent of the incubation time [64]. This fact indicates that flavonoids inhibit CAs probably through a mechanism similar to the one of phenol rather than hydrolysis of the chromenone as in the case of coumarins. 
<smiles>O=c1cc(-c2ccccc2)oc2ccccc12</smiles>

56<smiles>O=c1c(O)c(-c2ccccc2)oc2cccc(O)c12</smiles>

57<smiles>O=c1cc(-c2ccccc2)oc2cc(O)ccc12</smiles>

58<smiles>O=c1cc(-c2ccccc2)oc2cc(O)cc(O)c12</smiles>

59

Figure 12. Structures of compounds 56-59.

This hypothesis was further confirmed in several studies including flavonoids lacking the C-4 carbonyl group. A series of flavonoids 60-64 with different substitution patterns were investigated for their inhibitory effects against four $\alpha$-CA isozymes from human and bovine (hCA I, hCA II, bCA III, hCA IV) tissues: the flavones apigenin (60) and luteolin (61), the flavonols quercetin (62) and morin (63) and the flavan-3-ol, catechin (64) (Figure 13) [65]. As it can be observed from Table 6, flavonoids 60-64 were quite effective, similar to the standards used. The four hCA isozymes showed quite diverse inhibition profiles with these compounds suggesting that the type of flavonoid and/or substitution pattern are important for the activity. As briefly outlined above, the C-4 carbonyl group is not so important for the inhibition, as shown by the example of catechin (64). This is another indication that the inhibition mechanism does not proceed via hydrolysis (CA esterase activity). Instead, the presence of one or two neighboring hydroxyl groups is essential, as shown by the example of morin $\mathbf{6 7}$ which is the less potent compound compared to quercetin $\mathbf{6 2}$ or luteolin $\mathbf{6 1}$. The latter, $\mathbf{6 1}$ showed the most effective inhibitory activity with $\mathrm{K}_{\mathrm{I}} \mathrm{s}$ in the low micromolar range.<smiles>O=c1cc(-c2ccc(O)cc2)oc2cc(O)cc(O)c12</smiles>

60<smiles>O=c1cc(-c2ccc(O)c(O)c2)oc2cc(O)cc(O)c12</smiles>

61<smiles>O=c1c(O)c(-c2ccc(O)c(O)c2)oc2cc(O)cc(O)c12</smiles>

62<smiles></smiles>

63<smiles>Oc1cc(O)c2c(c1)O[C@H](c1ccc(O)c(O)c1)C(O)C2</smiles>

64

Figure 13. Structures of compounds 60-64.

Comparison with the relative monophenols, catechol, phenol and resorcinol (Figure 14), which were considerably less active, suggests that also the ring A of flavonoids may be involved in the inhibitory mechanism. Whether this is due to a different mechanism or simply stronger binding to the enzyme cavity (e.g., by further hydrogen bonds) is to be investigated in the future.<smiles>Oc1ccccc1</smiles>

phenol<smiles>Oc1ccccc1O</smiles>

catechol<smiles>Oc1cccc(O)c1</smiles>

Figure 14. Structures of basic phenol rings: phenol, catechol and resorcinol. 
Table 6. Inhibition of hCA isozymes I, II and IV and bCA III with compounds 60-64, EZA, ZNA and AZA by the esterase activity.

\begin{tabular}{ccccc}
\hline \multirow{2}{*}{ No. } & \multicolumn{4}{c}{ IC50 Value $(\boldsymbol{\mu M})^{\mathbf{a}}$} \\
\cline { 2 - 5 } & hCA I & hCA II & bCA II & hCA IV \\
\hline Apigenin (60) & 4.1 & 2.7 & 11.6 & 9.1 \\
Luteolin (61) & 2.2 & 0.74 & 5.4 & 4.4 \\
Quercetin (62) & 3.6 & 2.4 & 9.1 & 13.8 \\
Morin (63) & 12.8 & 4.4 & 21.3 & 15.7 \\
Catechin (64) & 6.8 & $6.2^{\mathrm{b}}$ & 2.2 & 5.6 \\
Phenol & 17.3 & 7.4 & 4.6 & 14.3 \\
Catechol & 4014 & 11.4 & 6.5 & 11.9 \\
Resorcinol & 828 & 9.4 & 219 & 634 \\
EZA & 3.7 & 0.32 & 9.4 & 0.84 \\
ZNA & 14.8 & 1.1 & 8.5 & 38.4 \\
AZA & 36.2 & 0.37 & 263 & 0.58 \\
\hline
\end{tabular}

${ }^{a}$ From three different assays, errors $\pm 5 \%-10 \%$ of the reported value; ${ }^{b}$ Values from Ref. [66].

Two further studies [46,67] with several flavonoids 60, 62, 64-71 (Figure 15, Tables 7 and 8) against human CA I, II, IV, VI and bovine CA III isoforms gave further evidence that the catechol moiety on C-2 enhances the activity, as demonstrated in the case of fisetin (66), rhamnetin (67) and rutin (69). Although a comparison between results of Tables 7-9 is not feasible due to the different enzymatic assays used and to different enzyme purities, it can be observed that catechin (64) and epicatechin (70) have similar activities despite different stereochemistry on C-3. Similarly, the hydroxyl group of C-3 seems to be of little importance for the activity. This is evident if we compare luteolin (61) with quercetin (62) (Table 6) and apigenin (60) with kaempferol (65) (Table 7). Therefore, the keto-enol system apparently does not take part in the inhibition mechanism. The better inhibitory activity of fisetin (66) and rhamnetin (67) should be attributed to structural differences in ring A. Interestingly, rutin (69) compared to flavonol aglycones such as quercetin (62) or rhamnetin (67) is more active suggesting that sugars may play an important role, as discussed previously.<smiles></smiles><smiles></smiles><smiles>COc1cc(O)c2c(=O)c(O)c(-c3ccc(O)c(O)c3)oc2c1</smiles><smiles>COc1cc(-c2oc3cc(O)cc(O)c3c(=O)c2O)ccc1O</smiles>

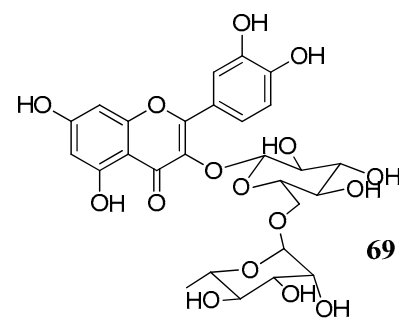<smiles></smiles>
70<smiles>COc1cc(C2Oc3ccc(C4Oc5cc(O)cc(O)c5CC4O)cc3OC3c4ccc(O)c(O)c4OC23)ccc1O</smiles>

Figure 15. Structures of compounds 65-71 [46,67]. 
Table 7. hCA isoforms I and II inhibition with compounds $\mathbf{6 0 , 6 4 - 7 0}$ by a stopped-flow, $\mathrm{CO}_{2}$ hydration assay [46].

\begin{tabular}{ccc}
\hline \multirow{2}{*}{ No. } & \multicolumn{2}{c}{ IC $_{\mathbf{5 0}}$ Value $(\mu \mathrm{g} / \mathrm{mL})^{\mathbf{a}}$} \\
\cline { 2 - 3 } & hCA I & hCA II \\
\hline Apigenin (60) & 1.22 & 1.14 \\
Catechin (64) & 1.24 & 0.87 \\
Kaempferol (65) & 0.83 & 0.76 \\
Fisetin (66) & 0.72 & 0.55 \\
Rhamnetin (67) & 0.95 & 0.86 \\
Isorhamnetin (68) & 0.52 & 0.36 \\
Rutin (69) & 1.44 & 0.52 \\
Epicatechin (70) & 1.47 & 1.02 \\
\hline${ }^{\text {a }}$ From three different assays, errors $\pm 5 \%-10 \%$ of the reported value.
\end{tabular}

Table 8. $K_{I}$ values $(\mu \mathrm{M})$ for compounds $60,62,64,69-71$ and AZA of some human $(\mathrm{h})$ and bovine (b) $\alpha$-carbonic anhydrase isoforms (by an esterase assay) [67].

\begin{tabular}{cccccc}
\hline \multirow{2}{*}{ No. } & \multicolumn{5}{c}{$\mathbf{K}_{\mathbf{I}} \mathbf{( n M )} \mathbf{a}^{\mathbf{a}}$} \\
\cline { 2 - 6 } & hCA I & hCA II & bCA III & hCA IV & hCA VI \\
\hline Apigenin (60) & 0.97 & 0.113 & 2.21 & 1.12 & 1.49 \\
Quercetin (62) & $2.68^{\mathrm{b}}$ & $2.54^{\mathrm{b}}$ & 3.73 & $7.89^{\mathrm{b}}$ & $6.17^{\mathrm{b}}$ \\
Catechin (64) & 1.73 & 0.83 & 4.77 & 3.76 & 7.82 \\
Rutin (69) & $2.42^{\mathrm{b}}$ & $1.84^{\mathrm{b}}$ & 9.71 & $4.09^{\mathrm{b}}$ & $4.91^{\mathrm{b}}$ \\
Epicatechin (70) & $2.32^{\mathrm{b}}$ & 1.24 & 8.93 & 3.98 & 4.36 \\
Silymarin (71) & $1.49^{\mathrm{c}}$ & $2.51^{\mathrm{c}}$ & 5.68 & $8.96^{\mathrm{c}}$ & $9.70^{\mathrm{c}}$ \\
AZA & $36.2^{\mathrm{c}}$ & $0.37^{\mathrm{c}}$ & 263 & 0.578 & 0.34 \\
\hline
\end{tabular}

a From three different assays, errors $\pm 5 \%-10 \%$ of the reported value; ${ }^{\mathrm{b}}$ Values from Ref. [68]; ${ }^{\mathrm{c}}$ Values form Ref. [66].

Table 9. Inhibition constant $\mathrm{K}_{\mathrm{I}}$ values $(\mu \mathrm{M})$ of human carbonic anhydrase I, II, VA, IX, and XII isoforms for compounds 60, 62, 65, 68, 72-77 and acetazolamide (AZA).

\begin{tabular}{cccccc}
\hline \multirow{2}{*}{ No. } & \multicolumn{5}{c}{$\left.\mathbf{K}_{\mathbf{I}} \mathbf{( n M}\right)^{\mathbf{a}}$} \\
\cline { 2 - 6 } & hCA I & hCA II & hCA VA & hCA IX & hCA XII \\
\hline Apigenin (60) & 4.10 & $2.70^{\mathrm{b}}$ & 0.30 & 0.46 & 1.00 \\
Quercetin (62) & 2.95 & 0.41 & 2.82 & 2.52 & 0.38 \\
Kaempferol (65) & 3.13 & 0.31 & 0.15 & 3.57 & 2.18 \\
Isorhamnetin (67) & $>10$ & 0.42 & 1.92 & 0.44 & 0.29 \\
Diosmetin (72) & $>10$ & $>10$ & 2.10 & 3.39 & 0.24 \\
Eriocitrin (73) & 3.66 & 0.34 & 4.24 & 0.43 & 0.19 \\
Hesperidin (74) & $3.60^{\mathrm{b}}$ & $2.40^{\mathrm{b}}$ & 2.65 & 2.22 & 0.45 \\
Naringin (75) & $>10$ & 0.41 & 4.08 & 3.59 & 0.17 \\
Taxifolin (76) & 2.53 & 0.26 & 3.93 & 0.45 & 0.11 \\
Quercetin-3-O-glucoside (77) & $>10$ & 0.44 & $>10$ & 2.79 & 0.22 \\
AZA & 0.10 & 0.008 & 0.38 & 0.041 & 0.038 \\
\hline
\end{tabular}

${ }^{a}$ From three different assays, errors $\pm 5 \%-10 \%$ of the reported value, $\mathrm{CO}_{2}$ hydrase, stopped-flow assay; ${ }^{\mathrm{b}}$ Values from Ref. [65].

A possible explanation of the way that flavonoids interact with the CA active site was given in a very interesting docking study by Gidaro et al., [69]. In this work a structure-based virtual screening was performed against five carbonic anhydrase isoforms using, as a ligand library, natural components of Citrus bergamia (Bergamot) and Allium cepa var. tropea (red onion). Both plants are edible and part of the Calabrian (Italy) diet. By use of virtual screening, the flavone apigenin $\mathbf{6 0}$ and the flavanone glycoside eriocitrin (eriodictyol-7-O-rutinoside) 73 (Figure 16) were identified together with other eight 
flavonoids. In vitro tests against CA I, II, VA, IX, and XII isoforms showed that eriocitrin was the best hCA VA inhibitor with a $\mathrm{K}_{\mathrm{I}}$ value of $0.15 \mu \mathrm{M}$. On the contrary, the computational prediction failed for apigenin. Docking studies revealed that eriocitrin probably binds by both the catechol and rutinoside portions. The catechol moiety is linked by additional H-bond interactions with the enzymatic residue Thr 199 located in the catalytic site, while the rutinose group connects by an extended H-bond network with several external mCA VA amino acid residues (Gln 67, Glu 69, Gln 92, Asp 171) at the entrance of the binding pocket. Apigenin instead, which was not as active as predicted, seems to interact only by its ring $B$ which is involved in the zinc coordination into the mCA VA active site.<smiles>[R7]Oc1ccc(-c2cc(=O)c3c(O)cc(O)cc3o2)cc1[R]</smiles>

Diosmetin $72 \mathrm{R}_{1}=\mathrm{OCH}_{3}, \mathrm{R}_{2}=\mathrm{OH}$

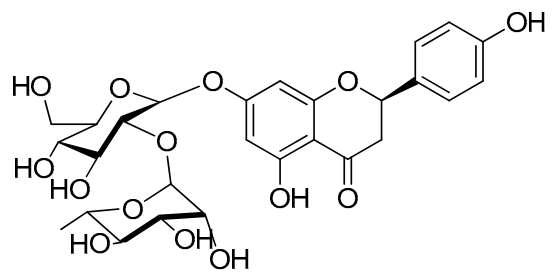

Naringin $\mathbf{7 5}$

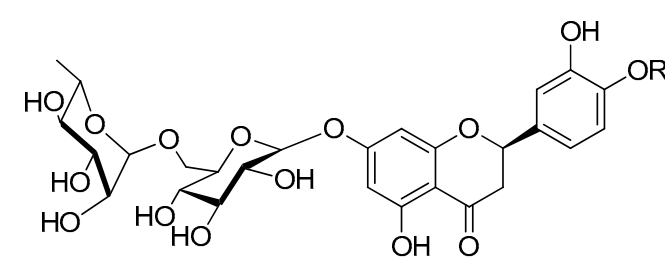

Eriocitrin $73 \mathrm{R}=\mathrm{H}$

Hesperidin $74 \mathrm{R}=\mathrm{CH}_{3}$<smiles>O=C1c2c(O)cc(O)cc2OC(c2ccc(O)c(O)c2)C1O</smiles>

Taxifolin $\mathbf{7 6}$<smiles>[R20]c1cc(-c2oc3cc(O)cc(O)c3c(=O)c2[R20])ccc1O</smiles>

Quercetin-3-O-glucoside, $77 \mathrm{R}_{1}=\mathrm{OCH}_{3}, \mathrm{R}_{2}=\mathrm{Glc}$

Figure 16. Structures of compounds 72-77 [69].

The lipophilic furanoflavonoid 78 from the bark of Millettia ovalifolia (Fabaceae) was considered for inhibition of the cytosolic form of the bovine carbonic anhydrase-II (Figure 17) [70]. Despite the lack of free hydroxyl groups in its structure it displayed significant inhibitory activity with $\mathrm{IC}_{50}$ value of $17.86 \pm 0.07 \mu \mathrm{M}$ (vs. zonisamide, $1.86 \pm 0.03$ ).<smiles>COc1ccc(-c2cc(=O)c3c(ccc4ccoc43)o2)cc1</smiles>

Figure 17. Structure of furanoflavonoid 78. 
The above reported results spurred us to investigate a larger number of flavonoids against a line of human CAs. In total, 18 flavonoids (Figure 18) were selected both from commercial sources and lab isolates [71]. The selection of the compounds was done on the basis of the flavonoid subgroup and the substitution pattern. Flavones, flavonols, flavanones, isoflavones and some glycosylated derivatives were considered for assays. Chrysin (79) is one of the main flavonoids of Passiflora incarnata, a medicinal plant used phytotherapy as a mild sedative and anxiolytic [72]. It is a flavone without any substitution of ring B. The flavone luteolin (61), the two flavonols kaempferol (65) and isorhamnetin (68), as well as the flavonol glycosides quercetin-3-O-glucoside (77), quercetin-3-O-rhamnoside (87) and kaempferol-3-O-glucoside (88) are ubipresent flavonoids in most vegetables and fruits daily consumed, while galangin $(\mathbf{8 0})$ is present in honey and propolis $[73,74]$. Among the flavonoids considered were the flavanones naringenin (81), eriodictyol (82) and hesperitin (83), which are abundant in edible Citrus spp. (e.g., orange, mandarin) and possess antioxidant, anti-inflammatory and antitumoral properties [75]. The isoflavones $\mathbf{8 4 - 8 5}$ are abundant in legumes, soy and show potent estrogenic activity by interacting with the estrogenic receptors [76,77]. Puerarin $(\mathbf{8 6})$ is the main active principle of Pueraria lobata root (Fabaceae) and it used in clinical practice in China to treat cardiovascular diseases, cerebrovascular disorders, Parkinson's disease, Alzheimer's disease, diabetes and diabetic complications [78]. The flavonols 89-91 were isolated from leaves of Quercus ilex (Fagaceae) and belong to the group of acylated flavonoids (Figure 19). Since they combine the flavonol nucleus and the coumaric acid moieties, they were selected with the aim to see whether we would have an additional inhibitory effect on the CAs. For the in vitro inhibitory activities five physiological relevant hCA isoforms were considered: the cytosolic I, II, VII and the membrane bound CA IV and XII. Results are displayed in Table 10.<smiles></smiles>

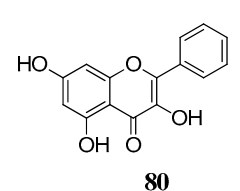<smiles>CC1(C)CC(=O)c2c(O)cccc2O1</smiles><smiles>Oc1ccc(-c2ccc(O)cc2O)c(O)c1</smiles><smiles>COc1ccc(-c2cc3c(O)c(O)c(O)cc3o2)cc1</smiles>

83<smiles>O=C1Oc2ccc(O)cc2C1c1ccc(O)cc1</smiles>

84<smiles>COc1ccc(C2Oc3cc(O)cc(O)c3C2=O)cc1</smiles>

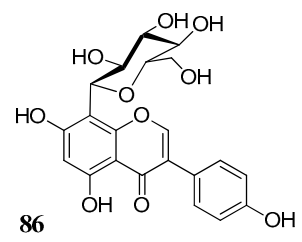

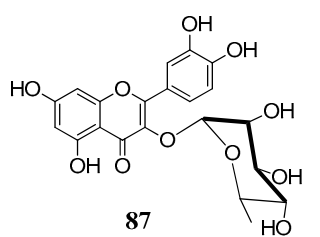

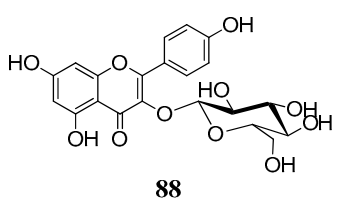

Figure 18. Structures of flavone $\mathbf{7 9}$, flavonol 80 , flavanones $81-83$, isoflavones 84,85 , isoflavone glucoside 86 and flavonol glycosides $\mathbf{8 7 - 8 8}$.
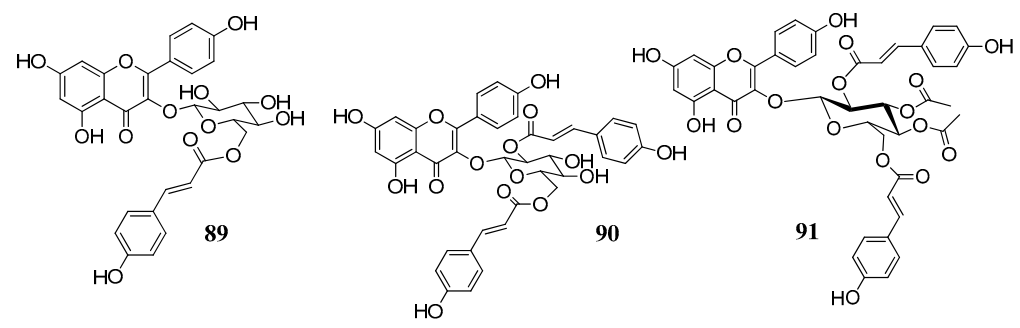

Figure 19. Structures of tested acylated flavonol glycosides 89-91 (isolated from Quercus ilex) [71]. 
Table 10. Inhibition data of human CA isoforms hCA I, II, IV, VII and XII with flavonoids 59, 63, 66, 74, $\mathbf{7 5}, \mathbf{7 6}-\mathbf{8 8}$ reported here and the standard sulfonamide inhibitor acetazolamide (AAZ) by a stopped flow $\mathrm{CO}_{2}$ hydrase assay.

\begin{tabular}{|c|c|c|c|c|c|c|}
\hline \multirow{2}{*}{ Entry } & \multirow{2}{*}{ Name } & \multicolumn{5}{|c|}{$\mathrm{K}_{\mathrm{I}}(\mathrm{nM})^{\mathrm{a}}$} \\
\hline & & hCA I & hCA II & hCA IV & hCA VII & hCA XII \\
\hline 79 & Chrysin & $>10,000$ & $>10,000$ & 537.75 & 171.41 & 34.7 \\
\hline 61 & Luteolin & $>10,000$ & 3691.6 & $293.0^{\mathrm{b}}$ & 4.7 & 60.3 \\
\hline 80 & Galangin & $>10,000$ & $>10,000$ & 568.3 & 24.5 & 41.8 \\
\hline 65 & Kaempferol & $>10,000$ & 9525.7 & $>10,000$ & 25 & 145.9 \\
\hline 67 & Isorhamnetin & $>10,000$ & $>10,000$ & 212.9 & 4.4 & 54.9 \\
\hline 81 & Naringenin & $>10,000$ & $>10,000$ & 79.5 & 4.3 & 44.3 \\
\hline 82 & Eriodictyol & $>10,000$ & $>10,000$ & 72.8 & 4.3 & 31.1 \\
\hline 83 & Hesperitin & $>10,000$ & $>10,000$ & 102.1 & 3.3 & 454.1 \\
\hline 76 & Taxifolin & $>10,000$ & $>10,000$ & 9098.2 & 493.1 & 32.5 \\
\hline 84 & Daidzein & $>10,000$ & $>10,000$ & 718.7 & 4.2 & 56.4 \\
\hline 85 & Biochanin A & $>10,000$ & $>10000$ & 7078.5 & 371.5 & 52.5 \\
\hline 86 & Puerarin & $>10,000$ & $>10,000$ & $>10,000$ & 452.6 & 515.0 \\
\hline 77 & Quercetin-3-O-glucoside & $>10,000$ & 6211.2 & 75.7 & 3.8 & 52.1 \\
\hline 87 & Quercetin-3-O-rhamnoside & $>10,000$ & 6367.7 & 67.3 & 3.9 & 43.5 \\
\hline 88 & Kaempferol-3-O-glucoside & $>10,000$ & 168.0 & 5591.2 & 423.7 & 4.9 \\
\hline 89 & Tiliroside & $>10,000$ & $>10,000$ & 5468.7 & 4.6 & 134.3 \\
\hline 90 & $\begin{array}{c}\text { Kaempferol-3-O-(2",6"-di-E- } \\
\text { p-coumaroyl)- } \beta \text {-glucopyranoside }\end{array}$ & $>10,000$ & 8790.2 & 344.2 & 4.7 & 408.9 \\
\hline \multirow[t]{2}{*}{91} & $\begin{array}{c}\text { Kaempferol-3-O-(3",4"-diacetyl-2",6"-di-E- } \\
\text { p-coumaroyl)- } \beta \text {-glucopyranoside }\end{array}$ & $>10,000$ & 6863.3 & 62.2 & 26.6 & 399.7 \\
\hline & AAZ & 250 & 12 & 74 & 2.5 & 5.7 \\
\hline
\end{tabular}

${ }^{a}$ Mean from three different assays, errors were in the range of $\pm 5 \%-10 \%$ of the reported values; ${ }^{b}$ From Ref. [65].

Although a SAR is difficult, some general remarks can be made. As can be observed from Table 10, none of the compounds considered here show a significant inhibitory activity against the cytosolic hCA I, but rather showed selectivity against isoforms hCA IV and hCAV II. Concerning the inhibition of hCA II, the presence of ortho-hydroxyl groups on ring B seems to be important for the activity as long as the double bond in ring $C$ remains intact. This is shown comparing luteolin with eriodictyol and taxifolin. Instead, glycosylation of the C-3 hydroxyl enhances the activity, as demonstrated by Kaempferol-3-O-glucoside which was the most active of all tested compounds with a $\mathrm{K}_{\mathrm{I}}$ of $168 \mathrm{nM}$.

Results were quite surprising regarding the inhibition hCA IV. The flavanones naringenin, eriodictyol and hesperitin, lacking the $\mathrm{C}_{2-3}$ double bond as well as the glycosides $77,87,91$ were quite effective against the with $\mathrm{K}_{\mathrm{I}}$ values close to the standard CAI acetazolamide $(74.0 \mathrm{nM})$. Especially comparing the activity of compounds $65,89-91$ it could be suggested that the optimum activity of compound 91 is not due to the flavonoid scaffold but to the acetyl/coumaric functionalities which may hydrolyze and released in situ. This hypothesis requires further investigation.

The kinetic data on the cytosolic hCA VII showed that several of the investigated compounds were low nanomolar inhibitors of the hCA VII with $\mathrm{K}_{\mathrm{I}}$ very close to the standard acetazolamide. Among the investigated constituents are the flavone luteolin (with ortho-hydroxyl groups) the flavonol isorhamnetin, the flavanones naringenin, eriodictyol and hesperitin, the isoflavone daidzein, the quercetin flavonols 77 and 87 and the acylated glycosides 89 and $\mathbf{9 0}$. With the exception of catechin, this is the first time that flavonoids are tested against this particular hCA isoform [68]. The heterogeneity of constituents does not permit any SAR conclusion or it is possible that some other common structural feature may be responsible for the inhibition, such as ring A or combination of rings A and B. Similarly, the inhibition data on the tumor associated hCA XII isoform (Table 10) showed a complex and different SAR. Generally most of the substances were high nanomolar inhibitors with $\mathrm{K}_{\mathrm{I}}$ values spanning between 515.0 and $134.3 \mathrm{nM}$. The best inhibitor evidenced was Kaempferol-3-O-glucoside with a $\mathrm{K}_{\mathrm{I}}$ value of $4.9 \mathrm{nM}$. The results in both hCAV II and XII show that flavonoids merit further attention and warrant future investigation to comprehend the mechanism of action in order to design new, selective inhibitors. 
A series of synthetic bischalcones $\mathbf{9 2 - 1 0 3}$ bearing a $\mathrm{C}-\mathrm{N}=\mathrm{N}-\mathrm{C}$ linkage has been prepared and tested against human hCA I and II (Figure 20) [79]. Most of the compounds had one to three methoxy groups as substituents on their phenolic rings. Compounds 93, 97, 101, and 103 were among the best inhibitors (Table 11). Furthermore, similarly to AZA, some of the investigated bischalcone compounds act as competitive inhibitors with 4-NPA as substrate, that is, they bind to the same regions of the active site cavity as the substrate. However, the binding site of 4-NPA itself is unknown, but it is presumed to be in the same region as that of $\mathrm{CO}_{2}$, the physiological substrate of this enzyme.
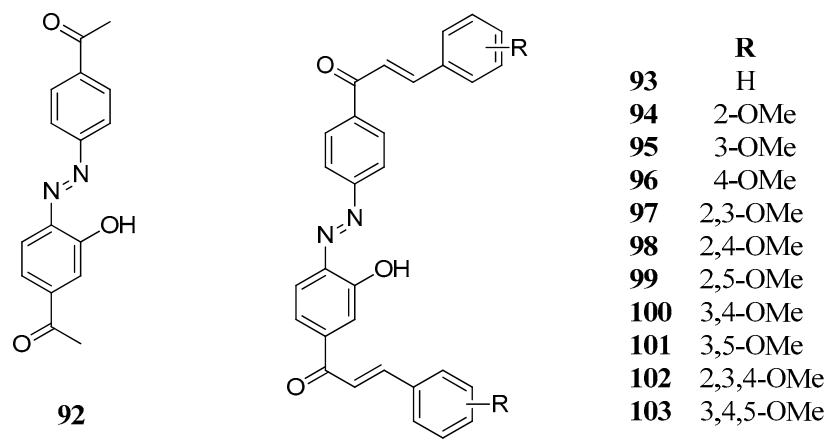

Figure 20. Structures of compounds 92-103.

Table 11. $\mathrm{K}_{\mathrm{I}}$ values of the compounds 92-103 (CA esterase activity).

\begin{tabular}{ccc}
\hline \multirow{2}{*}{ Compound } & \multicolumn{2}{c}{$\mathbf{K}_{\mathbf{I}}(\mathbf{n M})^{\mathbf{a}}$} \\
\cline { 2 - 3 } & hCA I & hCA II \\
\hline $\mathbf{9 2}$ & 274.19 & 645.39 \\
$\mathbf{9 3}$ & 112.34 & 154.45 \\
$\mathbf{9 4}$ & 325.12 & 418.06 \\
$\mathbf{9 5}$ & 165.35 & 227.56 \\
$\mathbf{9 6}$ & 308.88 & 307.52 \\
$\mathbf{9 7}$ & 111.22 & 193.19 \\
$\mathbf{9 8}$ & 177.91 & 446.62 \\
$\mathbf{9 9}$ & 188.56 & 208.53 \\
$\mathbf{1 0 0}$ & 323.30 & 182.31 \\
$\mathbf{1 0 1}$ & 72.90 & 166.54 \\
$\mathbf{1 0 2}$ & 179.11 & 268.87 \\
$\mathbf{1 0 3}$ & 103.55 & 319.13 \\
$\mathbf{A Z A}$ & 250.00 & 12.00 \\
\hline
\end{tabular}

a Mean from at least three determinations. Errors in the range of $\sim 3 \%$ of the reported value.

\subsection{Phenols and Polyphenols as Effective Mycobacterial CA Inhibitors}

The discovery of the $\alpha-, \beta-$, and $\eta$-families of carbonic anhydrase in parasitic bacteria, fungi protozoa and helminths with different structure than human CAs has created new opportunities in the search for new drugs against pathogens [29]. Since many pathogen carbonic anhydrases belong to different enzyme families, which are either absent in humans (like $\beta$ - and $\eta$-CAs) or have marked structural differences with the human isoforms they consist attractive targets for the development of new anti-infective agents in terms of selectivity and efficacy. Given the continuous development of resistance of several pathogens to the existing therapeutic schemes, CA inhibition represents a new, complementary mechanism of action worth of investigation. Among the most investigated CAs, are the $\beta$-CAs from Helicobacter pylori, Brucella suis and Mycobacterium tuberculosis, which have been cloned and characterized $[80,81]$. Other $\beta$-CAs which have been intensely studied are the CAs from the fungal strains Candida albicans, Candida glabrata and Cryptococcus neoformans: CaNce103 and CgNce103 (from C. albida and C. glabrata, respectively) and Can1, Can2 from C. neoformans. In these pathogens 
CAs regulate the physiological concentrations of $\mathrm{CO}_{2} / \mathrm{HCO}_{3}$. Both fungal strains are adapted to extremely low concentrations of $\mathrm{CO}_{2}$. However, once the infection occurs, elevated concentrations of $\mathrm{CO}_{2}$ promote distinct structural and developmental procedures which influence the survival, virulence and pathogenesis of these fungi [82].

The first evidence that phenols can inhibit pathogenic CAs came from the screening of a natural product library [83] against $\beta$-CAs from M. tuberculosis, C. albicans, and C. neoformans. Screening of libraries of plant extracts and isolated constituents, although time consuming, is a valuable tool in the exploration of new scaffolds in order to discover new chemotypes to combat diseases. The Queensland Compound Library reported by Davis et al., [83] comprised a wide range of natural and synthetic products incorporating the phenol group. Overall 21 constituents 104-124 were selected and tested (Figures 21 and 22) including eight fungal (compounds 104-109a, 112, 113), two ascidian (compounds 107, 108), and three plant (compounds 111-113) secondary metabolites. The tested structures were diverse comprising a series of simple mono- or disubstituted phenols 104-108, (-)-xylariamide A (109a) and its synthetic enantiomer (+)-xylariamide A (109b), polyandrocarpamine A (110), polyandrocarpamine B (111), xanthones 112 and 113, endiandrin A (114), endiandrin B (115) and (-)-dihydroguaiaretic acid 116. The synthetic phenolic compounds 117-124 (Figure 22) were eight secondary amides inspired by the fungal metabolite 108.

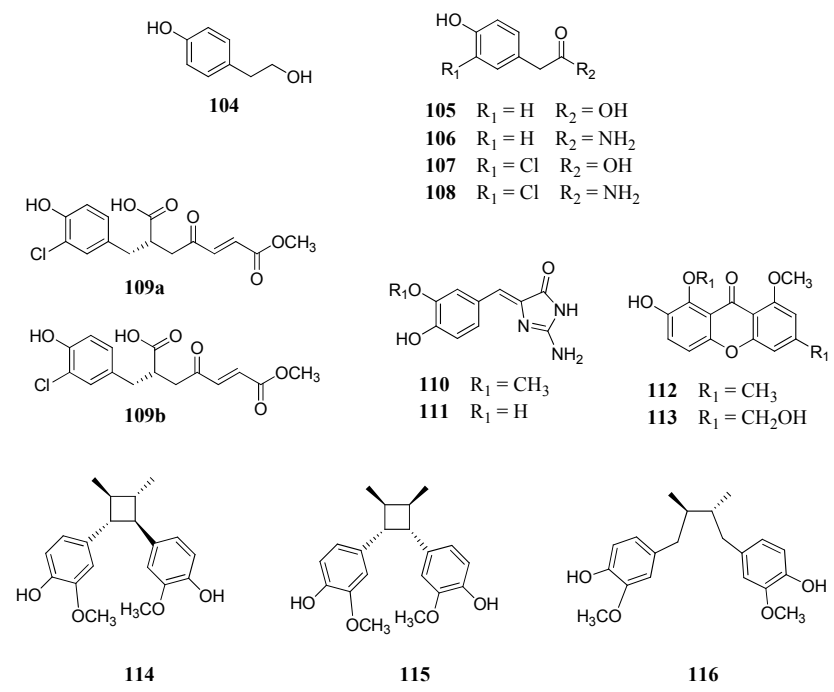

Figure 21. Structures of compounds 104-116.

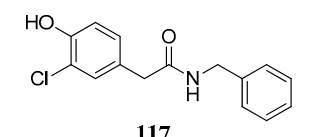

117

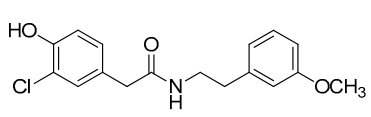

119

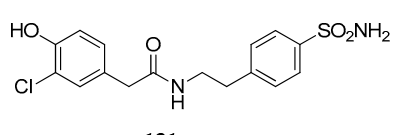

121<smiles>CC(C)(C)NC(=O)Cc1ccc(O)c(Cl)c1</smiles>

123
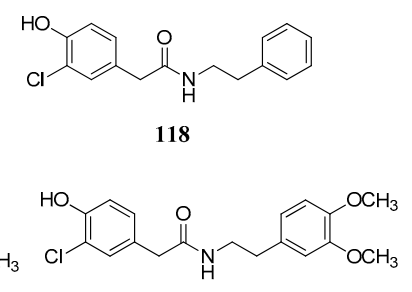

120

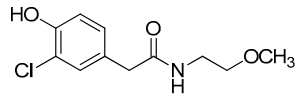

122

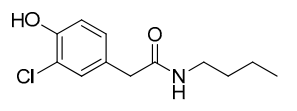

124

Figure 22. Structures of synthetic derivatives 117-124. 
Inhibition studies over human CAs were carried out in parallel in order to assess the selectivity of the tested compounds. As it can be observed from Table 12, several phenolic natural products were selective inhibitors of mycobacterial and fungal $\beta$-CAs.

Table 12. Enzyme inhibition of pathogenic M. tuberculosis $\beta$-CA isozymes Rv3273 and Rv1284, C. albicans isozyme Nce103, C. neoformans isozyme Can2 and human $\alpha$-CA isozymes I and II, with the NP-Based Library (104-124), known CA Inhibitors (SA, AZA, ZNS, and TPM) and phenol.

\begin{tabular}{|c|c|c|c|c|c|c|}
\hline \multirow{2}{*}{ Compound } & \multicolumn{6}{|c|}{$K_{I}(\mu M)^{a}$} \\
\hline & Rv3273 & Rv1284 & Nce103 & Can2 & CA I & CA II \\
\hline 104 & 12.1 & 0.85 & 1.10 & 1.08 & 430 & 8.711 .4 \\
\hline 105 & 11.4 & 10.8 & 1.02 & 0.90 & 309 & 10.3 \\
\hline 106 & 9.12 & 0.85 & 0.91 & 0.84 & 309 & 11.2 \\
\hline 107 & 10.8 & 10.3 & 1.08 & 1.12 & 265 & 8.6 \\
\hline 108 & 11.2 & 10.5 & 1.00 & 0.85 & 237 & 131 \\
\hline $109 a$ & 11.3 & 0.84 & 1.03 & 1.15 & 239 & 8.3 \\
\hline $109 b$ & 10.9 & 0.71 & 1.06 & 1.11 & 231 & 8.0 \\
\hline 110 & 0.91 & 11.8 & 0.92 & 0.89 & 10.5 & 9.6 \\
\hline 111 & 0.92 & 0.91 & 0.90 & 0.95 & 355 & 13.1 \\
\hline 112 & 11.4 & 10.5 & 1.06 & 1.12 & 201 & 8.4 \\
\hline 113 & 10.9 & 0.99 & 1.01 & 1.08 & 374 & 9.2 \\
\hline 114 & 8.92 & 0.82 & 0.73 & 0.77 & 368 & 11.7 \\
\hline 115 & 0.89 & 0.80 & 0.70 & 0.95 & 354 & 12.1 \\
\hline 116 & 9.10 & 0.85 & 0.62 & 0.81 & 307 & 230 \\
\hline 117 & 0.98 & 12.2 & 0.78 & 0.72 & 10.5 & 11.4 \\
\hline 118 & 0.97 & 0.80 & 0.93 & 0.81 & 9.6 & 9.8 \\
\hline 119 & 0.91 & 1.27 & 0.72 & 0.94 & 11.2 & 10.8 \\
\hline 120 & 0.90 & 1.78 & 0.75 & 0.86 & 11.9 & 11.5 \\
\hline 121 & 0.85 & 1.16 & 0.79 & 0.74 & 0.70 & 0.018 \\
\hline 122 & 1.14 & 11.0 & 0.99 & 0.95 & 158 & 10.4 \\
\hline 123 & 10.2 & 12.3 & 0.96 & 0.91 & 11.4 & 10.8 \\
\hline 124 & 10.4 & 11.6 & 0.81 & 0.73 & 10.7 & 9.4 \\
\hline SA & 7.11 & 9.84 & 7.63 & 0.77 & 25.0 & 0.24 \\
\hline AZA & 0.10 & 0.48 & 0.13 & 0.01 & 0.25 & 0.012 \\
\hline TPM & 3.02 & 0.61 & 1.11 & 0.37 & 0.25 & 0.010 \\
\hline ZNS & 0.21 & 286.8 & 0.94 & 0.97 & 0.056 & 0.035 \\
\hline Phenol & 79.0 & 64.0 & 17.3 & 25.9 & 10.1 & 5.5 \\
\hline
\end{tabular}

${ }^{\text {a }}$ Errors in the range of $\pm 5 \%$ of the reported value, from three determinations.

Among the natural products tested the best inhibitors was (-)-dihydroguaiaretic acid (116) which inhibited $\beta$-CA in the submicromolar range with up to 495-fold selectivity over hCA I and 371-fold selectivity over hCA II. From the library of synthetic derivatives, compound 108 was a low micromolar inhibitor of the fungal CAs and displayed 130- to 280-fold selectivity over the two human CAs. These compounds were the first non-sulfonamide inhibitors that displayed $\beta$ - over $\alpha$-CA enzyme selectivity. This selectivity could be explained if the different structure of $\alpha$ - and $\beta$-isozymes is taken into consideration. Although both enzymes contain a zinc ion in the active site, they have several differences. Unlike $\alpha$-CAs, the $\beta$-class of CAs exist as dimers (Figure 23). Whilst the catalytically important residues in the active site of $\beta$-CAs are provided exclusively from one monomer, access to the catalytic center may be constituted by residues from both monomers leaving a cleft of limited space for the inhibitor to enter. Therefore, it seems unlikely that the phenolic hydroxyl groups of the tested constituents directly interact with the active site zinc of the pathogen CAs, especially for the spacious one 116. It was suggested that the compounds might cause either monomerization or considerable conformational changes in the access area to the active site. To prove this concept crystallization of the adduct, and X-ray analysis is necessary. Unfortunately none of the tested compounds gave crystals with Can2, Nce103, Rv3273, and Rv1284 enzymes. 

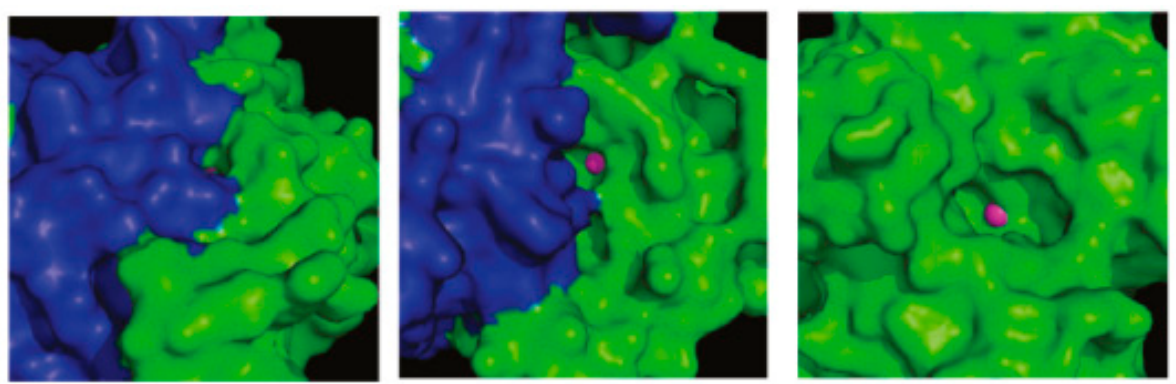

Figure 23. Comparison of accessible surface volumes of the active sites of M. tuberculosis Rv1284 (left, PDB accession code 1ylk), C. albicans Nce103 (middle, PDB accession code 3eyx), and human CA II (right, PDB accession code 3NB5). The individual monomers of the dimeric $\beta$-CAs are colored in green and blue, respectively. The catalytic zinc ion is shown in magenta. The figure was prepared with PyMol [84].

A series of phenolic acids 6-8 and some of their esters 125-132, derivatives of $p$-coumaric (6), caffeic (7) and ferulic acid (8), was investigated for the inhibition of three $\beta$-carbonic anhydrases (CAs, EC 4.2.1.1) from the pathogenic bacterium Mycobacterium tuberculosis, Rv1248, Rv3588 and Rv3273 $\beta$-CAs (Figure 24) [85]. Some of these compounds were low micromolar inhibitors of the pathogenic enzymes and they did not show inhibitory activity against the human widespread cytosolic isoforms CA I and II. As it can be observed from Table 13, simple phenolic acids 6-8 are active against Mtb $\beta$-CAs but suffer of low selectivity. The presence of additional phenolic rings in the structure makes the compounds more selective as it increases the ratio of $\beta$ - over $\alpha$-CA inhibitory activity. This is possibly due to additional interactions with the dimeric structure of the $\beta$-CA.<smiles>O=C(O)/C=C/c1ccc(O)cc1</smiles>

p-coumaric acid 6<smiles>O=C(O)/C=C/c1ccc(O)c(O)c1</smiles>

caffeic acid 7<smiles>COc1cc(/C=C/C(=O)O)ccc1O</smiles>

ferulic acid 8<smiles>O=C(/C=C/c1ccc(O)c(O)c1)OCCc1ccc(OCCc2ccc(O)cc2)cc1</smiles><smiles>O=C(/C=C/c1ccc(O)c(O)c1)OCCc1ccc(OCCc2cccc(O)c2)cc1</smiles>

126<smiles>COc1ccc(/C=C/C(=O)OCCc2ccccc2)cc1O</smiles>

127<smiles>COc1ccc(/C=C/C(=O)OCCc2ccc(O)cc2)cc1O</smiles><smiles>COc1ccc(/C=C/C(=O)OCCc2cccc(O)c2)cc1O</smiles><smiles>O=C(/C=C/c1ccc(O)cc1)OCCc1ccccc1</smiles><smiles>O=C(/C=C/c1ccc(O)cc1)OCCc1ccc(O)cc1</smiles>

131<smiles>O=C(/C=C/c1ccc(O)cc1)OCCc1cccc(O)c1</smiles>

Figure 24. Structures of compounds 6-8 and derivatives 125-132. 
Table 13. Inhibition of human CA isozymes I and II and Mtb CAs Rv1248, Rv3273 and with phenolic acids $\mathbf{6 - 8}$ and esters $\mathbf{1 2 2}-\mathbf{1 2 9}$ by a stopped flow $\mathrm{CO}_{2}$ hydrase assay.

\begin{tabular}{cccccc}
\hline \multirow{2}{*}{ Compound } & \multicolumn{5}{c}{$\mathbf{K}_{\mathbf{I}}(\boldsymbol{\mu M}) \mathbf{a}, \mathbf{b}$} \\
\cline { 2 - 6 } & hCA I & hCA II & Rv1248 & $\mathbf{R v 3 2 7 3}$ & Rv3588 \\
\hline $\mathbf{6}$ & 1.07 & 0.98 & 6.05 & 2.69 & 4.33 \\
$\mathbf{7}$ & 2.38 & 1.61 & 5.92 & 6.70 & 5.36 \\
$\mathbf{8}$ & 2.89 & 2.40 & 7.13 & 2.40 & 5.64 \\
$\mathbf{1 2 5}$ & 5.23 & $>50$ & 5.32 & 5.10 & 7.13 \\
$\mathbf{1 2 6}$ & 9.62 & $>50$ & 3.95 & 6.83 & 8.03 \\
$\mathbf{1 2 7}$ & $>50$ & $>50$ & 4.51 & 3.19 & 7.05 \\
$\mathbf{1 2 8}$ & $>50$ & $>50$ & 5.67 & 3.20 & 7.26 \\
$\mathbf{1 2 9}$ & $>50$ & $>50$ & 4.69 & 2.32 & 5.40 \\
$\mathbf{1 3 0}$ & $>50$ & $>50$ & 3.78 & 1.84 & 5.04 \\
$\mathbf{1 3 1}$ & 3.87 & $>50$ & 4.67 & 1.87 & 5.13 \\
$\mathbf{1 3 2}$ & 3.66 & $>50$ & 5.74 & 2.30 & 6.09 \\
\hline a Errors in the range of $+5 \%$ of the reported data from three different assays; ${ }^{\mathrm{b}} \mathrm{h}=$ human
\end{tabular}

Unfortunately it was not possible to obtain good quality crystals which would permit the study of the adduct by X-ray crystallography. To overcome this problem, the binding mode of these inhibitors to the bacterial enzymes Rv3588 and Rv1248 was investigated by computational approaches (Figures 25 and 26). A protocol consisting of classic MD and SMD simulations with molecular docking and rescoring was applied. It was proposed that the inhibitors anchor to the zinc-coordinated water molecule from the $\mathrm{CA}$ active site interfering with the nucleophilic attack of the zinc hydroxide on the substrate $\mathrm{CO}_{2}$. These compounds may be considered as interesting anti-mycobacterial lead compounds.

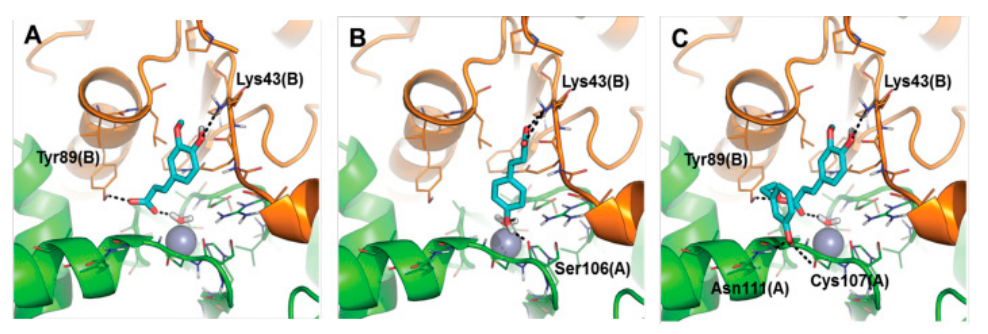

Figure 25. Predicted binding mode of 2 (panel A), 3 (panel B) and 8 (panel C) towards the active site of Rv3588 $\beta$-CA from Mtb. Monomer A is colored green, monomer B is colored orange. Small molecules are shown as cyan sticks. Residues within $5 \AA$ from the $\mathrm{Zn}$ (II) ion and those in contact with the inhibitors are shown as lines. H-bond interactions are highlighted by black dashed lines. Residues involved in $\mathrm{H}$-bonds are labeled. The catalytic $\mathrm{Zn}(\mathrm{II})$ ion is shown as a grey sphere [85].
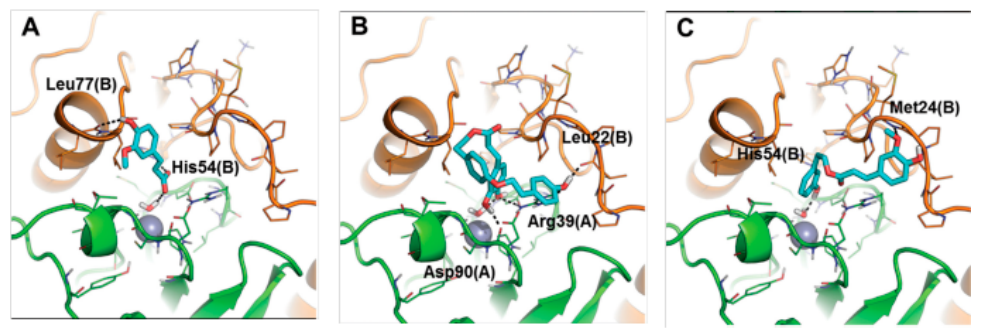

Figure 26. Predicted binding mode of 2 (panel A), 4 (panel B) and 8 (panel C) towards the active site of Rv1248 $\beta$-CA from Mtb. Monomer A is colored green, monomer B is colored orange. Small molecules are shown as cyan sticks. Residues within $5 \AA$ from the $\mathrm{Zn}$ (II) ion and those in contact with the inhibitors are shown as lines. H-bond interactions are highlighted by black dashed lines. Residues involved in $\mathrm{H}$-bonds are labeled. The catalytic $\mathrm{Zn}(\mathrm{II})$ ion is shown as a grey sphere [85]. 


\section{Conclusions}

Since the first discovery of activity of simple phenol as a competitive CA inhibitor and the elucidation of its inhibition mechanism, several phenolic derivatives have been investigated in detail for their interactions with the major physiological isoforms of hCAs. Among the natural products screened so far, phenols and polyphenols remain the most investigated ones. Studies including both natural products and synthetic derivatives have allowed the identification of selective inhibitors and demonstrated the enormous potential of this class of compounds. Due to their structural variety, these products are characterized by different selectivity profiles compared to the primary sulfonamides. The latter are the classical CA inhibitors with long use in clinical practice, which nevertheless suffer from pharmacological side effects. In the search for alternative isoform-selective inhibitors phenols and polyphenols are among the most promising constituents. The different mode of mechanism, which in many cases is unknown, creates new opportunities for drug design and development. However, given the immense variety of chemotypes of natural phenolics, there is still much to be explored. Quite recently they emerged as important probes against pathogen CAs with exceptional selectivity, opening a new way for the development of novel anti-infective agents. Further studies including in vitro and in vivo tests and disease models are necessary to confirm these results.

Acknowledgments: This work was financed the 7th framework program (Metoxia, Dynano) to C.T.S.

Author Contributions: A.K., F.C. and C.T.S. equally contributed to the work.

Conflicts of Interest: The authors declare no conflict of interest.

\section{References}

1. Supuran, C.T. Carbonic anhydrases: Novel therapeutic applications for inhibitors and activators. Nat. Rev. Drug Discov. 2008, 7, 168-181. [CrossRef] [PubMed]

2. Neri, D.; Supuran, C.T. Interfering with $\mathrm{pH}$ regulation in tumors as a therapeutic strategy. Nat. Rev. Drug Discov. 2011, 10, 767-777. [CrossRef] [PubMed]

3. Supuran, C.T.; Scozzafava, A.; Casini, A. Carbonic anhydrase inhibitors. Med. Res. Rev. 2003, 23, $146-189$. [CrossRef] [PubMed]

4. Ferry, J.G. The gamma class of carbonic anhydrases. Biochim. Biophys. Acta 2010, 1804, 374-381. [CrossRef] [PubMed]

5. Nishimori, I.; Onishi, S.; Takeuchi, H.; Supuran, C.T. The alpha and beta classes carbonic anhydrases from Helicobacter pylori as novel drug targets. Curr. Pharm. Des. 2008, 14, 622-630. [PubMed]

6. Krishnamurthy, V.M.; Kaufman, G.K.; Urbach, A.R.; Gitlin, I.; Gudiksen, K.L.; Weibel, D.B.; Whitesides, G.M. Carbonic anhydrase as a model for biophysical and physical-organic studies of proteins and protein-ligand binding. Chem. Rev. 2008, 108, 946-1051. [CrossRef] [PubMed]

7. Xu, Y.; Feng, L.; Jeffrey, P.D.; Shi, Y.; Morel, F.M. Structure and metal exchange in the cadmium carbonic anhydrase of marine diatoms. Nature 2008, 452, 56-61. [CrossRef] [PubMed]

8. Del Prete, S.; Vullo, D.; Fisher, G.M.; Andrews, K.T.; Poulsen, S.A.; Capasso, C.; Supuran, C.T. Discovery of a new family of carbonic anhydrases in the malaria pathogen Plasmodium falciparum-The $\eta$-carbonic anhydrases. Bioorg. Med. Chem. Lett. 2014, 18, 4389-4396. [CrossRef] [PubMed]

9. Kikutani, S.; Nakajima, K.; Nagasato, C.; Tsuji, Y.; Miyatake, A.; Matsuda, Y. Thylakoid luminal $\theta$-carbonic anhydrase critical for growth and photosynthesis in the marine diatom Phaeodactylum tricornutum. Proc. Natl. Acad. Sci. USA 2016, 113, 9828-9833. [PubMed]

10. Alterio, V.; Hilvo, M.; Di Fiore, A.; Supuran, C.T.; Pan, P.; Parkkila, S.; Scaloni, E.; Pastorek, J.; Pastorekova, S.; Pedone, C.; et al. Crystal structure of the catalytic domain of the tumor-associated human carbonic anhydrase IX. Proc. Natl. Acad. Sci. USA 2009, 106, 16233-16238. [CrossRef] [PubMed]

11. Alterio, V.; Di Fiore, A.; D'Ambrosio, K.; Supuran, C.T.; De Simone, G. X-ray crystallography of CA inhibitors and its importance in drug design. In Drug Design of Zinc-Enzyme Inhibitors: Functional, Structural, and Disease Applications; Supuran, C.T., Winum, J.Y., Eds.; Wiley: Hoboken, NJ, USA, 2009; pp. 73-138.

12. Carta, F.; Supuran, C.T.; Scozzafava, A. Sulfonamides and their isosters as carbonic anhydrase inhibitors. Future Med. Chem. 2014, 10, 1149-1165. [CrossRef] [PubMed] 
13. Masini, E.; Carta, F.; Scozzafava, A.; Supuran, C.T. Antiglaucoma carbonic anhydrase inhibitors: A patent review. Expert Opin. Ther. Pat. 2013, 6, 705-716. [CrossRef] [PubMed]

14. Scozzafava, A.; Supuran, C.T.; Carta, F. Antiobesity carbonic anhydrase inhibitors: A literature and patent review. Expert Opin. Ther. Pat. 2013, 6, 725-735. [CrossRef] [PubMed]

15. Carta, F.; Supuran, C.T. Diuretics with carbonic anhydrase inhibitory action: A patent and literature review (2005-2013). Expert Opin. Ther. Pat. 2013, 6, 681-691. [CrossRef] [PubMed]

16. Supuran, C.T.; Carta, F.; Scozzafava, A. Metalloenzyme inhibitors for the treatment of Gram-negative bacterial infections: A patent review (2009-2012). Expert Opin. Ther. Pat. 2013, 7, 777-788. [CrossRef] [PubMed]

17. Aggarwal, M.; Kondeti, B.; McKenna, R. Anticonvulsant/antiepileptic carbonic anhydrase inhibitors: A patent review. Expert Opin. Ther. Pat. 2013, 6, 717-724. [CrossRef] [PubMed]

18. Maresca, A.; Temperini, C.; Vu, H.; Pham, N.B.; Poulsen, S.A.; Scozzafava, A.; Quinn, R.J.; Supuran, C.T. Non-zinc mediated inhibition of carbonic anhydrases: Coumarins are a new class of suicide inhibitors. J. Am. Chem. Soc. 2009, 131, 3057-3062. [CrossRef] [PubMed]

19. Carta, F.; Temperini, C.; Innocenti, A.; Scozzafava, A.; Kaila, K.; Supuran, C.T. Polyamines inhibit carbonic anhydrases by anchoring to the zinc-coordinated water molecule. J. Med. Chem. 2010, 53, 5511-5522. [CrossRef] [PubMed]

20. Nair, S.K.; Ludwig, P.A.; Christianson, D.W. Two-site binding of phenol in the active site of human carbonic anhydrase II: Structural implications for substrate association. J. Am. Chem. Soc. 1994, 116, 3659-3660. [CrossRef]

21. Simonsson, I.; Jonsson, B.H.; Lindskog, S. Phenol, a competitive inhibitor of $\mathrm{CO}_{2}$ hydration catalyzed by carbonic anhydrase. Biochem. Biophys. Res. Commun. 1982, 108, 1406-1412. [CrossRef]

22. Lou, Y.; McDonald, P.C.; Oloumi, A.; Chia, S.K.; Ostlund, C.; Ahmadi, A.; Kyle, A.; Auf dem Keller, U.; Leung, S.; Huntsman, D.G.; et al. Targeting tumor hypoxia: suppression of breast tumor growth and metastasis by novel carbonic anhydrase IX inhibitors. Cancer Res. 2011, 71, 3364. [CrossRef] [PubMed]

23. Safety Study of SLC-0111 in Subjects with Advanced Solid Tumours. Available online: https://clinicaltrials. gov/ct2/show/NCT02215850 (accessed on 5 November 2016).

24. Riihonen, R.; Supuran, C.T.; Parkkila, S.; Pastorekova, S.; Väänänen, H.K.; Laitala-Leinonen, T. Membrane-bound carbonic anhydrases in osteoclasts. Bone 2007, 4, 1021-1031. [CrossRef] [PubMed]

25. Sun, M.K.; Alkon, D.L. Pharmacological enhancement of synaptic efficacy, spatial learning, and memory through carbonic anhydrase activation in rats. J. Pharmacol. Exp. Ther. 2001, 3, 961-967.

26. Hamidi, S.; Avoli, M. Carbonic anhydrase inhibition by acetazolamide reduces in vitro epileptiform synchronization. Neuropharmacology 2015, 95, 377-387. [CrossRef] [PubMed]

27. Ruusuvuori, E.; Kaila, K. Carbonic anhydrases and brain $\mathrm{pH}$ in the control of neuronal excitability. Subcell Biochem. 2014, 75, 271-290. [PubMed]

28. Arechederra, R.L.; Waheed, A.; Sly, W.S.; Supuran, C.T.; Minteer, S.D. Effect of sulfonamides as carbonic anhydrase VA and VB inhibitors on mitochondrial metabolic energy conversion. Bioorg. Med. Chem. 2013, 6, 1544-1548. [CrossRef] [PubMed]

29. Capasso, C.; Supuran, C.T. Bacterial, fungal and protozoan carbonic anhydrases as drug targets. Expert Opin. Ther. Targets 2015, 12, 1689-1704. [CrossRef] [PubMed]

30. Sein, K.K.; Aikawa, M. The pivotal role of carbonic anhydrase in malaria infection. Med. Hypotheses 1998, 1, 19-23. [CrossRef]

31. Krungkrai, J.; Supuran, C.T. The alpha-carbonic anhydrase from the malaria parasite and its inhibition. Curr. Pharm. Des. 2008, 7, 631-640. [CrossRef]

32. Harborne, J.B. General Procedures and measurement of total phenolics. In Methods in Plant Biochemistry; Plant Phenolics; Harborne, J.B., Dey, P.M., Eds.; Academic Press: San Diego, CA, USA, 1990; Volume 1, pp. 1-29.

33. Quideau, S.; Deffieux, D.; Douat-Casassus, C.; Pouységu, L. Plant Polyphenols: Chemical Properties, Biological Activities, and Synthesis. Angew. Chem. Int. Ed. 2011, 50, 586-621. [CrossRef] [PubMed]

34. Cheynier, V.; Comte, G.; Davies, K.M.; Lattanzio, V.; Martens, S. Plant phenolics: Recent advances on their biosynthesis, genetics, and ecophysiology. Plant Phys. Biochem. 2013, 72, 1-20. [CrossRef] [PubMed]

35. Dewick, P.M. The Shikimate Pathway: Aromatic amino acids and phenylpropanoids. In Medicinal Natural Products; John Wiley \& Sons, Ltd.: New York, NY, USA, 2002; pp. 121-165. 
36. Haslam, E. Polyphenols-vegetable tannins. In Plant Polyphenols Vegetable Tannins Revisited; Cambridge University Press: Cambridge, UK, 1989; pp. 1-13.

37. Khanbabaee, K.; van Ree, T. Tannins: Classification and Definition. Nat. Prod. Rep. 2001, 18, 641-649. [PubMed]

38. Andersen, Ø.M.; Markham, K.R. Flavonoids-Chemistry, Biochemistry and Applications; CRC/Taylor \& Francis Group: Boca Raton, FL, USA, 2006.

39. Gülçin, I. Antioxidant activity of food constituents: An overview. Arch. Toxicol. 2012, 86, 345-391. [CrossRef] [PubMed]

40. López-Malo Vigil, A.; Palou, E.; Alzamora, S.M. Naturally Occurring Compounds. In Plant Sources in Antimicrobials in Food, 3rd ed.; Davidson, P.M., Sofos, J.N., Branen, A.L., Eds.; CRC Press Taylor \& Francis Group: Boca Raton, FL, USA, 2005; pp. 429-451.

41. Clifford, M.; Brown, J.E. Dietary Flavonoids and Health-Broadening the Perspective. In Flavonoids: Chemistry, Biochemistry and Applications; Andersen, Ø.M., Markham, K.R., Eds.; Taylor \& Francis Group: Boca Raton, FL, USA, 2006; pp. 319-370.

42. Issa, A.Y.; Volate, S.R.; Wargovich, M.J. The role of phytochemicals in inhibition of cancer and inflammation: New directions and perspectives. J. Food Compos. Anal. 2006, 19, 405-419. [CrossRef]

43. Kelsey, N.A.; Wilkins, H.M.; Linseman, D.A. Nutraceutical Antioxidants as Novel Neuroprotective Agents. Molecules 2010, 15, 7792-7814. [CrossRef] [PubMed]

44. Supuran, C.T. Carbonic anhydrase inhibition with natural products: Novel chemotypes and inhibition mechanisms. Mol. Divers. 2011, 15, 305-316. [CrossRef] [PubMed]

45. Poulsen, S.-A.; Davis, R.A. Natural products that inhibit carbonic anhydrase. Sub-Cell. Biochem. 2014, 75, 325-334.

46. Sahin, H.; Can, Z.; Yildiz, O.; Kolayli, S.; Innocenti, A.; Scozzafava, G.; Supuran, C.T. Inhibition of carbonic anhydrase isozymes I and II with natural products extracted from plants, mushrooms and honey. J. Enzyme Inhib. Med. Chem. 2012, 27, 395-402. [CrossRef] [PubMed]

47. Tibell, L.; Forsman, C.; Simonsson, I.; Lindskog, S. The inhibition of human carbonic anhydrase II by some organic compounds. Biochim. Biophys. Acta 1985, 829, 202-208. [CrossRef]

48. Alterio, V.; Di Fiore, A.; D'Ambrosio, K.; Supuran, C.T.; de Simone, G. Multiple binding modes of inhibitors to carbonic anhydrases: How to design specific drugs targeting 15 different isoforms? Chem. Rev. 2012, 8, 4421-4468. [CrossRef] [PubMed]

49. Scozzafava, A.; Passaponti, M.; Supuran, C.T.; Gülçin, İ. Carbonic anhydrase inhibitors: Guaiacol and catechol derivatives effectively inhibit certain human carbonic anhydrase isoenzymes (hCA I, II, IX and XII). J. Enzyme Inhib. Med. Chem. 2015, 30, 586-591. [CrossRef] [PubMed]

50. Morris, J.C.; Chiche, J.; Grellier, C.; Lopez, M.; Bornaghi, L.F.; Maresca, A.; Supuran, C.T.; Pouysségu, J.; Poulsen, S.A. Targeting hypoxic tumor cell viability with carbohydrate-based carbonic anhydrase IX and XII inhibitors. J. Med. Chem. 2011, 54, 6905-6918. [CrossRef] [PubMed]

51. Winum, J.Y.; Colinas, P.A.; Supuran, C.T. Glycosidic carbonic anhydrase IX inhibitors: A sweet approach against cancer. Bioorg. Med. Chem. 2013, 21, 1419-1426. [CrossRef] [PubMed]

52. Riafrecha, L.E.; Rodriguez, O.M.; Vullo, D.; Supuran, C.T.; Colinas, P.A. Synthesis of C-cinnamoyl glycosides and their inhibitory activity against mammalian carbonic anhydrases. Bioorg. Med. Chem. 2013, 21, 1489-1494. [CrossRef] [PubMed]

53. Carreyre, H.; Coustard, J.M.; Carré, G.; Vandebrouck, C.; Bescond, J.; Ouédraogo, M.; Marrot, J.D.; Vullo, D.; Supuran, C.T.; Thibaudeau, S. Natural product hybrid and its superacid synthesized analogues: Dodoneine and its derivatives show selective inhibition of carbonic anhydrase isoforms I, III, XIII and XIV. Bioorg. Med. Chem. 2013, 21, 3790-3794. [CrossRef] [PubMed]

54. Carré, G.; Ouédraogo, M.; Magaud, C.; Carreyre, H.; Becq, F.; Bois, P.; Supuran, C.T.; Thibaudeau, S.; Vandebroucka, C.; Bescon, J. Vasorelaxation induced by dodoneine is mediated by calcium channels blockade and carbonic anhydrase inhibition on vascular smooth muscle cells. J. Ethnopharmacol. 2015, 169, 8-17. [CrossRef] [PubMed]

55. Topal, M.; Gülçin, I. Rosmarinic acid: A potent carbonic anhydrase isoenzymes inhibitor. Turk. J. Chem. 2014, 38, 894-902. [CrossRef]

56. Petersen, M.; Simmonds, M.S. Rosmarinic acid. Phytochemistry 2003, 62, 121-125. [CrossRef] 
57. Wang, M.; Karioti, A.; Bergonzi, M.C.; Gao, X.; Liu, Z.; Vincieri, F.F.; Bilia, A.R. Rapid isolation of salvianolic acid B from polar extracts of Salvia miltiorrhiza Bge. (Danshen). In Proceedings of the International Symposium, Traditional Chinese Medicine, Modernization of Acupuncture and Herbal Medicine Research, Graz, Austria, 14-16 May 2009.

58. Karioti, A.; Ceruso, M.; Carta, F.; Bilia, A.R.; Supuran, C.T. New natural product carbonic anhydrase inhibitors incorporating phenol moieties. Biorg. Med. Chem. 2015, 23, 7219-7225. [CrossRef] [PubMed]

59. Bonaccini, L.; Karioti, A.; Bergonzi, M.C.; Bilia, A.R. Effects of Salvia miltiorrhiza on CNS Neuronal Injury and Degeneration: A Plausible Complementary Role of Tanshinones and Depsides. Planta Med. 2015, 81, 1003-1016. [CrossRef] [PubMed]

60. Ho, J.H.C.; Hong, C.Y. Salvianolic acids: Small compounds with multiple mechanisms for cardiovascular protection. J. Biomed. Sci. 2011, 18, 1-5. [CrossRef] [PubMed]

61. Wu, W.Y.; Wang, Y.P. Pharmacological actions and therapeutic applications of Salvia miltiorrhiza depside salt and its active components. Acta Pharmacol. Sin. 2012, 33, 1119-1130. [CrossRef] [PubMed]

62. Maresca, A.; Akyuz, G.; Osman, S.M.; AlOthman, Z.; Supuran, C.T. Inhibition of mammalian carbonic anhydrase isoforms I-XIV with a series of phenolic acid esters. Bioorg. Med. Chem. 2015, 23, 7181-7188. [CrossRef] [PubMed]

63. Burmaoğlu, S.; Dilek, E.; Yılmaz, A.O.; Supuran, C.T. Synthesis of two phloroglucinol derivatives with cinnamyl moieties as inhibitors of the carbonic anhydrase isozymes I and II: An in vitro study. J. Enzym. Inhib. Med. Chem. 2016. [CrossRef] [PubMed]

64. Balboni, G.; Congiu, C.; Onnis, V.; Maresca, A.; Scozzafava, A.; Winum, J.-Y.; Maietti, A.; Supuran, C.T. Flavones and structurally related 4-chromenones inhibit carbonic anhydrases by a different mechanism of action compared to coumarins. Bioorg. Med. Chem. Lett. 2012, 22, 3063-3066. [CrossRef] [PubMed]

65. Ekinci, D.; Karagoz, L.; Ekinci, D.; Senturk, M.; Supuran, C.T. Carbonic anhydrase inhibitors: In vitro inhibition of $\alpha$ isoforms (hCA I, hCA II, bCA III, hCA IV) by flavonoids. J. Enzym. Inhib. Med. Chem. 2013, 28, 283-288. [CrossRef] [PubMed]

66. Sentürk, M.; Gülçin, I.; Beydemir, S.; Küfrevioglu, O.I.; Supuran, C.T. In Vitro Inhibition of Human Carbonic Anhydrase I and II Isozymes with Natural Phenolic Compounds. Chem. Biol. Drug Des. 2011, 77, 494-499. [CrossRef] [PubMed]

67. Koz, Ö.; Ekinci, D.; Perrone, A.; Piacente, S.; Çalışkan, O.A.; Bedir, E.; Supuran, C.T. Analysis of saponins and phenolic compounds as inhibitors of $\alpha$-carbonic anhydrase isoenzymes. J. Enzym. Inhib. Med. Chem. 2013, 28, 412-417. [CrossRef] [PubMed]

68. Innocenti, A.; Beyza Oztórk Sarikaya, S.; Gülçin, I.; Supuran, C.T. Carbonic anhydrase inhibitors. Inhibition of mammalian isoforms I-XIV with a series of natural product polyphenols and phenolic acids. Bioorg. Med. Chem. 2010, 18, 2159-2164. [CrossRef] [PubMed]

69. Gidaro, M.C.; Alcaro, F.; Carradori, S.; Costa, G.; Vullo, D.; Supuran, C.T.; Alcaro, S. Eriocitrin and apigenin as new carbonic anhydrase VA inhibitors from a virtual screening of calabrian natural products. Planta Med. 2015, 81, 533-540. [PubMed]

70. Rahman, T.U.; Khatta, K.F.; Liaqa, W.; Zama, K.; Musharra, S.G. Characterization of one Novel Flavone and four New Source Compounds from the Bark of Millettia ovalifolia and In-Vitro Inhibition of Carbonic Anhydrase-II by the Novel Flavonoid. Rec. Nat. Prod. 2015, 9, 553-560.

71. Karioti, A.; Bilia, A.R.; Skaltsa, H. Quercus ilex: A rich source of polyacylated flavonoid glucosides. Food Chem. 2010, 123, 131-142. [CrossRef]

72. Miroddi, M.; Calapai, G.; Navarra, M.; Minciullo, P.L.; Gangemi, S. Passiflora incarnata L.: Ethnopharmacology, clinical application, safety and evaluation of clinical trials. J. Ethnopharmacol. 2013, 150, 791-804. [PubMed]

73. Huang, H.; Chen, A.Y.; Rojanasakul, Y.; Ye, X.; Rankin, G.O.; Chen, Y.C. Dietary compounds galangin and myricetin suppress ovarian cancer cell angiogenesis. J. Funct. Foods 2015, 15, 464-475. [CrossRef] [PubMed]

74. González-Gallego, J.; García-Mediavilla, M.V.; Sánchez-Campos, S.; Tuñón, M.J. Fruit polyphenols, immunity and inflammation. Br. J. Nutr. 2010, 104, S15-27. [CrossRef] [PubMed]

75. Kamran Khan, M.; Huma, Z.E.; Dangles, O. A comprehensive review on flavanones, the major citrus polyphenols. J. Food Compost. Anal. 2014, 33, 85-104. [CrossRef]

76. Taku, K.; Melby, M.K.; Nishi, N.; Omori, T.; Kurzer, M.S. Soy isoflavones for osteoporosis: An evidence-based approach. Maturitas 2011, 70, 333-338. [CrossRef] [PubMed] 
77. Vitale, D.C.; Piazza, C.; Melilli, B.; Drago, F.; Salomone, S. Isoflavones: Estrogenic activity, biological effect and bioavailability. Eur. J. Drug Metab. Pharmacokinet. 2013, 38, 15-25. [CrossRef] [PubMed]

78. Zhou, Y.X.; Zhang, H.; Peng, H. Puerarin: A Review of Pharmacological Effects. Phytother. Res. 2014, 28, 961-975. [CrossRef] [PubMed]

79. Arslan, T.; Çelik, G.; Çelik, H.; Şentürk, M.; Yayl, N.; Ekinci, D. Synthesis and Biological Evaluation of Novel Bischalcone Derivatives as Carbonic Anhydrase Inhibitors. Arch. Pharm. Chem. Life Sci. 2016, 349, 741-748. [CrossRef] [PubMed]

80. Joseph, P.; Turtaut, F.; Ouahrani-Bettache, S.; Montero, J.-L.; Nishimori, I.; Minakuchi, T.; Vullo, D.; Scozzafava, A.; Köhler, S.; Winum, J.-Y.; et al. Cloning, characterization, and inhibition studies of a $\beta$-carbonic anhydrase from Brucella suis. J. Med. Chem. 2010, 53, 2277-2285. [CrossRef] [PubMed]

81. Joseph, P.; Ouahrani-Bettache, S.; Montero, J.-L.; Nishimori, I.; Minakuchi, T.; Vullo, D.; Scozzafava, A.; Winum, J.-Y.; Köhler, S.; Supuran, C.T. A new $\beta$-carbonic anhydrase from Brucella suis, its cloning, characterization, and inhibition with sulfonamides and sulfamates, leading to impaired pathogen growth. Bioorg. Med. Chem. 2011, 19, 1172-1178. [CrossRef] [PubMed]

82. Elleuche, S.; Pöggeler, S. Carbonic anhydrases in fungi. Microbiology 2010, 156, 23-29. [CrossRef] [PubMed]

83. Davis, R.A.; Hofmann, A.; Osman, A.; Hall, R.A.; Mühlschlegel, F.A.; Vullo, D.; Innocenti, A.; Supuran, C.T.; Poulsen, S.A. Natural Product-Based Phenols as Novel Probes for Mycobacterial and Fungal Carbonic Anhydrases. J. Med. Chem. 2011, 54, 1682-1692. [CrossRef] [PubMed]

84. DeLano, W. The PyMOL Molecular Graphics System. Available online: http://www.pymol.org (accessed on 5 November 2016).

85. Cau, Y.; Mori, M.; Supuran, C.T.; Botta, M. Mycobacterial carbonic anhydrase inhibition with phenolic acids and esters: Kinetic and computational investigations. Org. Biomol. Chem. 2016, 14, 8322-8330. [CrossRef] [PubMed]

(C) 2016 by the authors; licensee MDPI, Basel, Switzerland. This article is an open access article distributed under the terms and conditions of the Creative Commons Attribution (CC-BY) license (http://creativecommons.org/licenses/by/4.0/). 